This is the peer reviewed version of the following article:

Seagrasses in an era of ocean warming: a review.

First published: 20 May 2021

which has been published in final form at

https://onlinelibrary.wiley.com/doi/10.1111/brv.12736

This article may be used for non-commercial purposes in accordance with Wiley Terms and Conditions for Self-Archiving." 


\section{Seagrasses in an era of ocean warming: a review}

Hung M. Nguyen ${ }^{1}$, Peter J. Ralph ${ }^{2}$, Lázaro Marín-Guirao ${ }^{1,3, *,}$, Mathieu

Pernice $^{2, \S}$ and Gabriele Procaccini ${ }^{1, \S}$

${ }^{1}$ Stazione Zoologica Anton Dohrn, Villa Comunale, 80121 Napoli, Italy

${ }^{2}$ University of Technology Sydney, Faculty of Science, Climate Change Cluster (C3), Sydney,

New South Wales 2007, Australia

${ }^{3}$ Seagrass Ecology Group, Oceanographic Centre of Murcia, Spanish Institute of

Oceanography, C/Varadero, 30740 San Pedro del Pinatar, Murcia, Spain

*Author for correspondence (E-mail: lazaro.marin@ieo.es; Tel.: 0034-619-729-004).

${ }^{\S}$ Authors contributed equally. 


\section{ABSTRACT}

Seagrasses are valuable sources of food and habitat for marine life and are one of Earth's most efficient carbon sinks. However, they are facing a global decline due to ocean warming and eutrophication. In the last decade, with the advent of new technology and molecular advances, there has been a dramatic increase in the number of studies focusing on the effects of ocean warming on seagrasses. Here, we provide a comprehensive review of the future of seagrasses in an era of ocean warming. We have gathered information from published studies to identify potential commonalities in the effects of warming and the responses of seagrasses across four distinct levels: molecular, biochemical/physiological, morphological/population, and ecosystem/planetary. To date, we know that although warming strongly affects seagrasses at all four levels, seagrass responses diverge amongst species, populations, and over depths. Furthermore, warming alters seagrass distribution causing massive die-offs in some seagrass populations, whilst also causing tropicalization and migration of temperate species. In this review, we evaluate the combined effects of ocean warming with other environmental stressors and emphasize the need for multiple-stressor studies to provide a deeper understanding of seagrass resilience. We conclude by discussing the most significant knowledge gaps and future directions for seagrass research.

Key words: seagrasses, ocean warming, climate change, multiple-stressor studies, seagrass die-off, tropicalization, ocean solution, conservation, restoration. 


\section{CONTENTS}

I. Introduction

(1) Global warming is happening at an alarming rate

(2) Seagrasses are being impacted by ocean warming

(3) Why is this review timely?

II. Effects of warming on seagrasses

(1) Effects of warming and seagrass responses at the molecular level

(a) Heat shock proteins

(b) Oxidative stress

(c) Other molecular responses

(d) Intraspecific differences in molecular responses to warming amongst seagrass populations from different thermal origins

(e) Epigenetic modification

(2) Effects of warming and seagrass responses at the physiological/biochemical level

(a) Physiological responses

(b) Biochemical responses

(3) Effects of warming and seagrass responses at the morphological/population level

(a) Morphological responses

(b) Population responses

(4) Effects of warming and seagrass responses at the ecosystem/planetary level

(5) Combined effects of warming and other stressors

(a) Warming and salinity changes

(b) Warming and light limitation

(c) Warming and sulphide stress

(d) Warming and eutrophication 
(e) Warming and herbicides

(f) Warming and pathogens

(g) Warming and herbivores

III. Future perspectives

(1) Enlarging the number of species and populations studied

(2) Developing more precise and detailed seagrass distribution maps

(3) Long-term monitoring programs

(4) More realistic experiments in controlled conditions

(5) The study of the holobiont

(6) Seagrasses as a solution to mitigate climate change

IV. Conclusions

V. Acknowledgements

VI. References

VII. Supporting information 


\section{I. INTRODUCTION}

\section{2 (1) Global warming is happening at an alarming rate}

3 Since the beginning of the industrial revolution in the mid-18th century, human activities

4 have been continuously releasing billions of tons of $\mathrm{CO}_{2}$ into the atmosphere (e.g. 10.4

5 billion tons in 2011). This has resulted in a massive increase in atmospheric $\mathrm{CO}_{2}$

6 concentration from $\sim 280 \mathrm{ppm}$ in the 1700s (Monastersky, 2013) to over $419 \mathrm{ppm}$ at the

7 beginning of 2021 (https://www.co2.earth/) contributing to the greenhouse effect (Anderson,

8 Hawkins \& Jones, 2016). This human-induced phenomenon has led to irreversible changes to

9 the Earth's climate, with global warming the strongest consequence (Solomon et al., 2009;

10 Shakun et al., 2012): the temperature of the Earth's surface increased by $0.61 \pm 0.16^{\circ} \mathrm{C}$ between 1861 and 2000 (Keller, 2009). Exceeding the tipping point of $1.5^{\circ} \mathrm{C}$ above preindustrial global temperature level is predicted to cause irreversible global-ecosystem shifts that will challenge the existence of millions of species, including humans (Masson-Delmotte et al., 2018; Lenton et al., 2019). Global warming is not only reflected by a pronounced upward trend in the average global temperature, but also by an increased frequency of extreme thermal events (i.e. heatwaves) (Meehl \& Tebaldi, 2004; Christidis, Jones \& Stott, 2015). For instance, the European heatwave of 2003 was one of the most significant examples of such abnormal climatic events with extremely hot and dry weather causing widespread environmental, economic, and social consequences (Schär \& Jendritzky, 2004). Covering over $70 \%$ of the Earth's surface, the ocean plays a fundamental role in the Earth's climate, and is a habitat for an estimated $50-80 \%$ of all life on Earth. Global warming is also affecting the ocean, which is warming at an alarming rate, especially in coastal areas, where the temperature increase has been reported as $0.17 \pm 0.11^{\circ} \mathrm{C} / \mathrm{decade}$ (Liao et al., 2015). In semi-closed seas (e.g. the Red Sea and the Mediterranean Sea), the rate is even faster (Nguyen et al., 2020a). 
In the sea, thermal conditions are more stable than on land (except for the intertidal zone).

Recent studies have documented a rapid rise in the occurrence of extreme climatic events in the ocean, known as marine heatwaves (MHWs) (Oliver et al., 2018). MHWs are extreme warm periods that last for at least five days with a temperature level exceeding the 90th percentile, based on three-decade historical baseline temperature values (Hobday et al., 2016). Ocean warming, and especially MHWs, is already having catastrophic consequences in coastal benthic communities worldwide (Coma et al., 2009; Harley et al., 2012; Wernberg et al., 2016). Indeed, the impact of MHWs is of more concern than the increase in average seawater temperature, because organisms are generally more vulnerable to sudden temperature changes than to progressive ones (Smale et al., 2019). Thus, MHWs may trigger destructive chronic impacts on marine creatures that can result in shifts in species distributions and even local extinctions (Easterling et al., 2000).

\section{(2) Seagrasses are being impacted by ocean warming}

Seagrasses are a unique group of angiosperms that recolonized the marine realm $60-90$ million years ago on at least three occasions (Les, Cleland \& Waycott, 1997). To overcome the numerous challenges presented by a submerged lifestyle in the marine environment, seagrasses have developed a range of specialized adaptive characteristics (Invers, Perez \& Romero, 1999; Borum et al., 2007; Wissler et al., 2011; Hogarth, 2015; Olsen et al., 2016). Consisting of a surprisingly small number of species ( $\sim 60-70$ species in total), seagrasses are distributed across thousands of kilometres of sedimentary shorelines from sub-Artic to tropical regions (Short et al., 2007). They provide highly valuable socio-economic services, including primary productivity, organic carbon sequestration and burial, as well as sediment stabilization (Orth et al., 2006; Fourqurean et al., 2012; Bertelli \& Unsworth, 2014; Unsworth, Nordlund \& Cullen-Unsworth, 2019). They also provide nursery habitats for fish 
and a diversity of marine organisms (e.g. invertebrates). Seagrasses represent one of the most valuable ecosystems on Earth with an estimated value of \$1.9 trillion per annum (Waycott et al., 2009; Costanza et al., 2014). Furthermore, they have been acknowledged as one of Earth's most efficient carbon sinks, and are listed as one of the potential solutions to mitigate $\mathrm{CO}_{2}$ emissions and ultimately to address the threat of global warming (Gattuso et al., 2018). Despite their critical value, they are suffering a global decline, driven mainly by the growing number of pressures linked directly to human activities (e.g. ocean warming, coastal modification, water quality degradation) (Orth et al., 2006; Waycott et al., 2009). Globally, seagrasses are disappearing at an alarming rate of $110 \mathrm{~km}^{2}$ per annum, resulting in a cumulative loss of $29 \%$ of the total world seagrass population by the end of 2006 (Waycott et al., 2009). The total population of Posidonia oceanica, for example, a seagrass species endemic to the Mediterranean Sea, has decreased by $13-50 \%$ since the mid-nineteenth century (Telesca et al., 2015). However, the rate of seagrass loss, at least at a regional scale, seems to have been reduced as a result of the implementation of management plans, such as European environmental protection measures (de los Santos et al., 2019).

A recent study listed seagrasses as one of the habitat-forming species that are likely to disappear as a consequence of climate change (Trisos, Merow \& Pigot, 2020). Seagrass dieoffs, as a consequence of MHWs, have been reported for different species, including $P$. oceanica (Marbà \& Duarte, 2010), Zostera marina (Reusch et al., 2005; Jarvis, Brush \& Moore, 2014), and Amphibolis antarctica (Seddon, Connolly \& Edyvane, 2000; Arias-Ortiz et al., 2018; Strydom et al., 2020). The observed mass mortality of several seagrass populations after extreme MHWs (Arias-Ortiz et al., 2018; Strydom et al., 2020) and the projected warming trend for the next decades has motivated the prediction of a functional extinction of seagrass meadows in the near future (Marbà \& Duarte, 2010; Jordà, Marbà, \& Duarte, 2012; Chefaoui, Duarte \& Serrão, 2018). Interestingly, while MHWs have already 
caused extensive local extinction of seaweed species across hundreds of kilometres (Smale, 2020), the comparative effects on seagrasses might appear to be smaller. This suggests that further research investigating the mechanisms driving potential differences in the resilience between seagrasses and other marine macrophytes is clearly needed.

\section{(3) Why is this review timely?}

The recent application of advanced molecular technologies in seagrass research (see review by Davey et al., 2016) together with the implementation of controlled laboratory manipulations have enabled rapid progress in the understanding of seagrass responses to changing environments (Egea et al., 2019; Saha et al., 2019). Moreover, the availability of the first two sequenced seagrass genomes, for Z. marina (Olsen et al., 2016) and Zostera muelleri (Lee et al., 2016), has enhanced seagrass molecular research.

Over the last decade, there has been a rapid increase in the number of studies documenting the impact of warming on seagrasses as well as the responses of seagrasses to this environmental challenge (Fig. 1). These studies have investigated the response of seagrasses to warming at the biological level (i.e. biochemical, physiological and morphological), and also at the molecular, population and even ecosystem/planetary level (Fig. 1). A review on the effects of warming on seagrasses is timely since: (1) ocean warming is occurring at an alarming rate and will continue to have strong impacts on seagrasses in the future; (2) a substantial amount of information on the effects of warming on seagrasses has become available recently; and (3) there is no comprehensive review on the effects of ocean warming on seagrasses [but see Bulthuis, 1987; Lee, Park \& Kim, 2007a; Koch et al., 2013; Duarte et al., 2018]. This review focuses on the effects of warming on seagrasses across different functional levels (molecular, biochemical/physiological, morphological/population and ecosystem/planetary), describes the effects of warming on seagrasses in combination with 
other stressors (e.g. salinity, light, etc.), and suggests future research directions to close knowledge gaps in our understanding of seagrass resilience in a changing climate.

\section{EFFECTS OF WARMING ON SEAGRASSES}

\section{(1) Effects of warming and seagrass responses at the molecular level}

In the face of rapid ocean warming, it is critically important to predict the future responses of seagrasses in order to develop mitigation strategies to prevent their loss through effective management, conservation, and restoration. The molecular basis of seagrass responses to a warming ocean can uncover seagrass traits that can be correlated to the persistence of that species under changing climatic conditions (Procaccini, Olsen \& Reusch, 2007; Reusch \& Wood, 2007). Innovative molecular experiments in parallel with routine physiological/morphological measurements can provide early warning measures to detect changes in the ecological status of seagrass meadows well before any signs of mortality appear (Procaccini et al., 2007; Pernice et al., 2015; Schliep et al., 2015; Ceccherelli et al., 2018). The extensive application of gene expression studies (transcriptomics) over the last decade (Davey et al., 2016) and the availability of two seagrass genomes, Z. marina (Olsen $e t$ al., 2016) and Z. muelleri (Lee et al., 2016), have greatly fostered our understanding of seagrass responses to environmental changes at the molecular level (see Fig. 1C). We are now much closer to integrating the fields of seagrass ecophysiology and ecological genomics, as anticipated almost a decade ago (Procaccini et al., 2012).

To date, gene expression studies (quantitative reverse transcription polymerase chain reaction and RNA sequencing) have been conducted for only a handful of seagrass species. Large transcriptomic differences observed in seagrasses that had recovered from long-term acute temperature stress $\left(3\right.$ weeks at $26^{\circ} \mathrm{C}$ ) identified transcriptomic resilience as a predictor of thermal adaptation (Franssen et al., 2011; Jueterbock et al., 2016). Other studies found 
different transcriptomic responses to short-term acute stress ( 5 days, $\left.32^{\circ} \mathrm{C}\right)$, leading to the identification of molecular mechanisms involved in maintaining photosynthetic stability and respiratory acclimation of seagrasses under heat stress (Marín-Guirao et al., 2017).

Investigations of the responses of seagrasses to thermal stress have revealed some interspecific similarities (see Fig. 2), comparable to those observed in the heat response of terrestrial plants, including refolding of proteins, activation of oxidative-stress defence, and cell wall fortification (Franssen et al., 2011, 2014; Gu et al., 2012; Jueterbock et al., 2016; Marín-Guirao et al., 2016, 2017).

\section{(a) Heat shock proteins}

Seagrasses have developed several sophisticated molecular mechanisms to respond to environmental triggers. Among these mechanisms, the production of chaperones, especially heat shock proteins (HSPs) are among the most important. HSPs are common proteins found in both plants and animals. They play fundamental roles in cells under normal and stressed conditions, including roles in protein folding, assembly, translocation, and protein degradation (Vierling, 1991; Kiang \& Tsokos, 1998; Park \& Seo, 2015). Under stressful conditions, HSPs can either help to fix non-functional/partly denatured proteins or remove degraded/damaged proteins (Sørensen, Kristensen \& Loeschcke, 2003).

Multiple studies have highlighted the role of molecular chaperones (especially HSPs) in seagrass responses to warming (Reusch et al., 2008; Bergmann et al., 2010; Franssen et al., 2011, 2014; Massa et al., 2011; Gu et al., 2012; Marín-Guirao et al., 2016, 2017; Tutar et al., 2017; Malandrakis et al., 2017; Traboni et al., 2018; Purnama et al., 2019; Nguyen et al., 2020a). HSP70 and HSP90 are the best studied chaperones in seagrasses. In terrestrial plants, heat shock factors (HSFs) act as transcriptional activators of HSPs and some have a critical role in plant thermal tolerance (Qu et al., 2013). It remains mostly unclear whether HSFs 
have the same role in seagrasses compared with terrestrial plants, although some of these genes have been shown to be responsive in at least two seagrass species (Zostera noltii and $P$. oceanica) when exposed to rapid and severe heat stress (Massa et al., 2011; Marín-Guirao et al., 2016).

\section{(b) Oxidative stress}

Oxidative stress, generated by the enhanced production of reactive oxygen species (ROS) under increased temperatures, is a common secondary stress response in plants (Hasanuzzaman, Nahar \& Fujita, 2013). Gene expression studies in different seagrass species strongly support the involvement of genes encoding ROS-scavengers, indicating the production of ROS in seagrasses during thermal stress (Reusch et al., 2008; Winters et al., 2011; Gu et al., 2012; Liu et al., 2016; Marín-Guirao et al., 2017; Tutar et al., 2017; Purnama et al., 2019). In seagrasses, superoxide dismutase (SOD) and ascorbate peroxidase (APX) appear to be among the most active ROS-scavenging enzymes under heat stress (Reusch et al., 2008; Winters et al., 2011; Liu et al., 2016; Marín-Guirao et al., 2017; Purnama et al., 2019). These enzymes have been shown to inhibit free radicals and ROS (Teotia \& Singh, 2014).

Using a metabolomics approach, Gu et al. (2012) detected myo-inositol among the three most responsive metabolites to oxidative stress in two seagrass species (Z. marina and Z. noltii) subjected to heat stress. In terrestrial plants, myo-inositol is important in the galactinol and raffinose biosynthetic pathways that have been characterized as osmoprotectants. These osmoprotectants can function as scavengers of ROS (Nishizawa, Yabuta, \& Shigeoka, 2008) whereas myo-inositol alone has been found to increase the midpoint denaturation temperature of proteins (Ortbauer \& Popp, 2008). 
177 Apart from HSPs and ROS-scavenging proteins, other mechanisms by which seagrasses respond to warming have been discovered in recent molecular studies. Gu et al. (2012) on Z. marina and Traboni et al. (2018) on P. oceanica revealed the involvement of ubiquitination and proteolysis in response to thermal stress, indicative of severe protein damage as a consequence of elevated temperature. In terrestrial plants, ubiquitin-mediated proteolysis is a multi-step process that identifies, labels, and destroys damaged proteins. It is the principal mechanism of protein catabolism to facilitate plant proteostasis when exposed to stressful conditions (reviewed by Stone, 2014). The cell wall is fundamentally important for the survival and development of plants as it provides a structural framework and is the first line of defence against pathogens. Moreover, cell wall modification can enhance plant responses to many environmental stressors (reviewed by Houston et al., 2016). In seagrasses, transcriptomic studies revealed higher expression of cell wall-related genes in plants exposed to thermal stress, suggesting the potential involvement of cell wall fortification in the thermal stress response as in terrestrial plants (Gu et al., 2012; Franssen et al., 2014; Jueterbock et al., 2016; Marín-Guirao et al., 2017, 2019).

Warming can have detrimental effects on the translational machinery of seagrasses, by limiting the availability of associated molecular components (Malandrakis et al., 2017) with destructive consequences on the organization of the cytoskeleton (Massa et al., 2011; Malandrakis et al., 2017; Tutar et al., 2017) which can in turn damage cell division processes (Malandrakis et al., 2017; Marín-Guirao et al., 2017). Furthermore, warming can diminish the expression of pathogen defence genes, thereby potentially enhancing susceptibility to disease (Jueterbock et al., 2016) although experimental evidence to date suggests the contrary (see Section II.5f). Given the past massive die-off of seagrass meadows due to "wasting 
disease' (Orth et al., 2006), the combined effects of warming and disease deserve further investigation.

Warming causes damage to DNA and protein structure (e.g. protein unfolding, protein degradation) in seagrasses, resulting in homeostatic cell imbalance and cell death (Franssen et al., 2011; Tutar et al., 2017). Under severe conditions, seagrasses activate apoptotic pathways by upregulating expression levels of genes involved in the programmed cell death process aimed at eliminating irreparably damaged cells (Massa et al., 2011; Tutar et al., 2017; Traboni et al., 2018). This apoptotic mechanism is also connected with the production of HSPs (Beere, 2005).

(d) Intraspecific differences in molecular responses to warming amongst seagrass populations from different thermal origins

Seagrass populations from different thermal origins respond differently to warming. Plants living in more fluctuating and/or warmer environments are more resilient to warming than those from colder and/or more stable thermal environments. Examples include Z. marina from different latitudes (Bergmann et al., 2010; Franssen et al., 2011; Winters et al., 2011; Jueterbock et al., 2016; Jahnke et al., 2019), P. oceanica from different depths (Marín-Guirao et al., 2016, 2017; Tutar et al., 2017; Procaccini et al., 2017) and latitudes (Marín-Guirao et al., 2019), and Halophila stipulacea from the Red Sea and Mediterranean Sea (Nguyen et al., 2020a). Plants from warm environments (i.e. Z. marina from southern populations and $P$. oceanica from shallow meadow stands) activate a more complete (i.e. higher number of upregulated genes) and intense (i.e. stronger activation of heat-responsive genes) transcriptomic response than plants from cold environments (Z. marina from northern populations, $P$. oceanica from deep-water populations) (Franssen et al., 2014; Marín-Guirao et al., 2017). 
responsive genes, likely reflecting their local (pre-)adaptation to warmer and more stressful thermal conditions. Higher constitutive expression levels of heat-responsive genes have been associated with a pre-adaptive defence strategy that confers higher thermal tolerance to cope with frequent heat stress in several marine organisms, including corals and marine gastropods (Barshis et al., 2013; Gleason \& Burton, 2015). While plants from southern and northern European populations of Z. marina reacted similarly to acute heat stress (Franssen et al., 2011), they differed in their global transcriptome recovery after the temperature returned to 'normal'. This phenomenon is known as transcriptomic resilience and may be part of a more universal indicator of whether or not plants can endure critical temperatures or other stressor levels.

\section{(e) Epigenetic modification}

Studies regarding epigenetic modifications are now emerging in the field of seagrass molecular biology (Jueterbock et al., 2020; Nguyen et al., 2020b). Epigenetic modifications are molecular modifications that alter gene expression in response to internal (e.g. ontogenetic processes) or external (e.g. environmental changes) triggers, without changes in the underlying DNA sequence (Bossdorf, Richards \& Pigliucci, 2008). Epigenetic modifications are inherited through mitosis in most cases, but are also transmittable to the next generation. While epigenetic modifications have been widely studied in terrestrial plants (Chinnusamy \& Zhu, 2009; Kinoshita \& Seki, 2014; Liu et al., 2015), only a few studies have investigated epigenetic responses to warming in seagrasses (Ruocco et al., 2019a,b; Jueterbock et al., 2020; Nguyen et al., 2020b; Entrambasaguas, L., Ruocco, M., Verhoeven, K.J.F., Procaccini, G. \& Marín-Guirao, L., in preparation). Some transcriptomic data sets suggest the involvement of epigenetic modification in the responses of seagrasses to thermal stress (Marín-Guirao et al., 2017; Marín-Guirao et al., 2019; Jueterbock et al., 2020). For 
example, in $P$. oceanica, heat-tolerant plants showed higher expression of epigenetic-related genes (Marín-Guirao et al., 2017; Marín-Guirao et al., 2019). Stress-induced epigenetic mechanisms are crucial in the activation of the immediate stress response and favour both short- and long-term adaptation, due to their important role in regulating the expression of stress-related genes (Liu et al., 2015). Increased knowledge on the epigenetic responses of plants to environmental changes in terrestrial systems (Molinier et al., 2006; Feng \& Jacobsen, 2011; Kinoshita \& Seki, 2014; Wang et al., 2016), and the possible application of more advanced molecular technologies (Kurdyukov \& Bullock, 2016; Van Wesenbeeck et al., 2018) may stimulate further study of epigenetic modification in seagrasses.

\section{(2) Effects of warming and seagrass responses at the physiological/biochemical level}

Biochemical and physiological response to thermal stress in seagrasses have been studied extensively since the 1990s (Fig. 1C), with earlier studies summarized in previous reviews (Bulthuis, 1987; Lee et al., 2007a; Koch et al., 2013). Thermal stress tends to inhibit photosynthetic activity while simultaneously enhancing respiration. Recent findings suggest that extreme temperature changes could cause the degradation of chlorophyll as well as affecting the fluidity of the cellular membrane, among other impacts. In response to thermal stress, seagrasses tend to activate protective mechanisms such as the accumulation of photoprotective pigments and modification of fatty acid contents (see Fig. 2).

\section{(a) Physiological responses}

Warming affects seagrass physiological and metabolic processes including photosynthesis and respiration (Bulthuis, 1987; Lee et al., 2007a). Under mild temperature increments, photosynthetic rate increases, likely due to an increase in membrane fluidity that improves the mobility of photosynthetic proteins embedded within the thylakoid membrane (e.g. the 
plastoquinone pool). Other factors, such as temperature-enhanced enzyme activity, may also play a role. Further temperature increases, however, reduce photosynthetic rate due to factors such as the detachment of functional proteins from the thylakoid membrane (e.g. PSII antenna, oxygen-evolving complex) and the inactivation of Rubisco (Sharkey, 2005; Allakhverdiev et al., 2008).

The optimal temperature for photosynthesis differs between tropical $\left(27-33{ }^{\circ} \mathrm{C}\right)$ and temperate $\left(21-32^{\circ} \mathrm{C}\right)$ seagrasses (Lee et al., 2007a). Beyond this optimal window, warming negatively alters the functioning of the photosynthetic apparatus. The reaction centre of photosystem II (PSII) is one of the most thermally sensitive components together with processes driving the electron transport chain, stromal enzymes, PSI activity, and chloroplast envelopes. Damage to PSII due to thermal stress can cause a reduction of effective quantum yield and maximum quantum yield, due to a significant increase in minimum fluorescence level ( $\left.F_{0}\right)$ (Marín-Guirao et al., 2016, 2017, 2018; Nguyen et al., 2020a,b). In terrestrial plants, an increase in $F_{0}$ is one of the clearest indications of PSII inactivation due to thermal stress (Allakhverdiev et al., 2008). The key enzymes of the carbon fixation cycle (Rubisco and Rubisco activase) are also highly sensitive to heat stress, as a secondary consequence of disruptions in the thylakoid membrane (Salvucci \& Crafts-Brandner, 2004), thereby disturbing carbon fixation (Marín-Guirao et al., 2016). Extreme thermal stress can result in degradation of photosynthetic pigments ( $\mathrm{Chl} a$ and $\mathrm{Chl} b$ ) together with the accumulation of chlorophyll degradation products (pheophytin $a$ and pheophytin $b$ ), further reducing photosynthetic capacity (Repolho et al., 2017; Beca-Carretero et al., 2018a; Nguyen et al., $2020 a, b)$. Seagrasses commonly activate a photo-protective mechanism associated with xanthophyll cycle pigments to deal with excess energy in the photosynthetic apparatus resulting from heat-stress-associated photosynthetic inhibition (Marín-Guirao et al., 2016; 
299 Ontoria et al., 2019a). This mechanism is linked with increased concentrations of the photo300 protective pigments zeaxanthin, antheraxanthin, and violaxanthin (York et al., 2013).

301 Plants with a history of high thermal fluctuation, or grown in warmer waters show less

302 photosynthetic thermal-induced damage than those from colder origins or more stable

303 temperature regimes [e.g. P. oceanica (Marín-Guirao et al., 2016, 2017, 2018); Cymodocea

304 nodosa (Marín-Guirao et al., 2018); H. stipulacea (Nguyen et al., 2020a); Cymodocea

305 serrulata, Halodule uninervis and Z. muelleri (Collier et al., 2017)]. Additionally, it has

306 recently become evident that leaf tissues of different age exhibit variable thermal plasticity

307 and activate different strategies to withstand heat stress (Ruocco et al., 2019a).

308 In $P$. oceanica, the strong induction of a complete set of genes encoding functional and structural proteins of the thylakoid electron transport chain may be part of the molecular mechanisms underlying the enhanced photosynthetic stability of seagrasses in response to heat stress (Marín-Guirao et al., 2017). This strong transcriptomic reprogramming could favour the turnover of relevant parts of the photosynthetic apparatus, enabling correct electron flow and thus protecting the thylakoid membranes from heat impairment.

Together with impacts on photosynthesis, warming enhances respiration rates in seagrasses resulting in a carbon imbalance (Lee et al., 2007a; Marín-Guirao et al., 2016, 2018; Yaping et al., 2019). In most cases, the respiration rate of the above-ground part of the plant is higher in comparison to the below-ground parts (Collier et al., 2017). The increase in above- to below-ground biomass ratio during thermal stress seen in many seagrass species may represent a defensive mechanism to lower the impact of thermal-induced elevated respiration (Collier, Uthicke \& Waycott, 2011; Olsen et al., 2012; Marín-Guirao et al., 2018). 
323 Modification of cell membrane fluidity is a common response of plants under stressful conditions including thermal stress. When exposed to increased temperatures, the viscosity of the lipid bilayer of cell membranes changes, leading to increased membrane fluidity, which can potentially affect the function of molecules embedded in or attached to the membrane (e.g. the water-splitting complex bonded to the thylakoid membrane). The ability to adjust the fatty acid content and composition of cell membranes plays a central role in the modification of membrane fluidity to cope with temperature changes. An increase in saturated fatty acid content makes the membrane less fluid and more stable under increased temperatures (Gaur \& Sharma, 2014). Seagrasses can increase the amount of saturated fatty acid and decrease the number of unsaturated fatty acids, thus maintaining membrane fluidity in response to thermal stress (Beca-Carretero et al., 2018b). Beca-Carretero et al. (2018b) showed that (1) seagrasses from a warm climate (southwest Mediterranean) were able to adjust their lipid components rapidly in response to rising temperatures compared with their counterparts from the colder northwest Mediterranean, and (2) the fast-growing $C$. nodosa had a greater capacity to manipulate its lipid components compared with the slow-growing $P$. oceanica. Furthermore, modification of lipid content, ultrastructure, and microtubule organization all play an important role in stabilizing cell membrane fluidity under thermal stress conditions (Koutalianou, Orfanidis, \& Katsaros, 2016).

In thermal stress conditions, most terrestrial plants increase the storage of soluble and insoluble (starch) sugars to maintain a stable energy supply, membrane function, and to reduce the impact of increased respiration rates (Guy et al., 2007). Similarly, both tropical (Halodule wrightii and Thalassia testudinum; Koch et al., 2007) and temperate seagrasses (P. oceanica and C. nodosa; Marín-Guirao et al., 2018) significantly increased their sugar content in response to increased water temperature. Only the plants from warm regions were able to re-allocate additional carbohydrate content from leaves (higher respiration rate) to 
rhizomes (lower respiration rate). This mechanism reduces the negative impact of thermalenhanced respiration, allowing the plants to survive better under elevated thermal stress (Marín-Guirao et al., 2018). A comparison of the results from Koch et al. (2007) and MarínGuirao et al. (2018) show that the tropical seagrasses $H$. wrightii and T. testudinum were better able to manage respiration stress through manipulation of carbohydrate content compared with the temperate species $C$. nodosa and $P$. oceanica.

(3) Effects of warming and seagrass responses at the morphological/population level

(a) Morphological responses

Warming has a strong effect on seagrass growth rates (Collier et al., 2011; Olsen et al., 2012; Collier \& Waycott, 2014; Hammer et al., 2018; Kim et al., 2019; Marín-Guirao et al., 2018; Nguyen et al., 2020a,b), leaf traits (York et al., 2013; Nguyen et al., 2020a), and leaf/shoot number (Mayot, Boudouresque \& Leriche, 2005; Nejrup \& Pedersen, 2008; Beca-Carretero et al., 2018a; Nguyen et al., 2020a). While modification of the above-ground part can result in a reduction of above- to below-ground biomass ratio (York et al., 2013; Collier et al., 2017; Marín-Guirao et al., 2018), warming can also increase the above- to below-ground biomass ratio in rapid-growing seagrass species (see Collier et al., 2011; Marín-Guirao et al., 2018), reducing the biomass of non-photosynthetic (below-ground) tissues and increasing photosynthetic biomass to offset the negative impacts of heat stress-enhanced respiration (see also Fig. 2).

(b) Population responses

In response to ocean warming, seagrass meadows can acclimatize or adapt to environmental changes (i.e. acclimation/adaptation: $1 \rightarrow 2$ in Fig. 3). Seagrass meadows that normally experience large fluctuations in environmental parameters such as temperature, light, etc. are 
more likely to be able to survive ocean warming (Massa et al., 2009; Collier et al., 2011; Marín-Guirao et al., 2018; Soissons et al., 2018). In addition, the resilience of seagrass meadows depends on the genetic diversity of the population (Williams, 2001; Hughes \& Stachowicz, 2004; Ehlers, Worm \& Reusch, 2008). There is some evidence of local adaptation both in adjacent and distant meadows, and therefore it is difficult to generalize the effects observed in specific populations (Jueterbock et al., 2016; Marín-Guirao et al., 2016, 2018).

In monospecific populations, plant responses to warming can be delayed and can be genotype specific (Reynolds et al., 2016a). During this recovery phase, the genotypic diversity of natural populations determines their resilience to MHWs in term of both the immediate response and recovery (Ehlers et al., 2008; Reusch et al., 2005). In meadows composed of different species, co-occurring species can change in relative abundance due to different heat sensitivities (Richardson, Lefcheck \& Orth, 2018) or differ in their ability to recover and recolonize after the perturbation (Nowicki et al., 2017). These changes can affect the structure and function of seagrass ecosystems and their resilience. Ocean warming usually favours small- and medium-sized species at the expense of larger species, reduces meadows structure, and decreases function and resilience as seen in the case of the small seagrass $H$. stipulacea (Winters et al., 2020).

Warming can also alter flowering in seagrasses, thus providing an escape mechanism through sexual reproduction and seed dispersal (escape in space and time: $1 \rightarrow 3$ in Fig. 3). Warming induces flowering in some species (Diaz-Almela, Marbà \& Duarte, 2007; Ruiz et al., 2018) and advances the onset of flowering in other cases (Blok, Olesen \& Krause-Jensen, 2018; Marín-Guirao et al., 2019). In the case of the clonal and long-lived P. oceanica, flowering has been linked to a heat stress response with potential adaptive consequences (Marín-Guirao et al., 2019). Through sexual reproduction, warming induces an increase in genetic diversity 
of seagrass populations, thus potentially sustaining the resilience of that seagrass meadow (Massa et al., 2009; Collier et al., 2011; Marín-Guirao et al., 2018; Soissons et al., 2018). Sexual reproduction provides seagrasses with an escape mechanism not only in space, but also in time. In some seagrass species, their seeds have a resting stage, which can last up to two years (e.g. Zostera, Halodule and Syringodium; reviewed by Orth et al., 2000). In other species, seagrass seeds can be dispersed over long distances by floating fruits (e.g. up to 55 km for for P. australis; Ruiz-Montoya et al., 2012) or by mega-herbivores like dugongs (Dugong dugon) and green sea turtles (Chelonia mydas) which can help to spread seagrass seeds as far as $650 \mathrm{~km}$ away from the parental plants (Tol et al., 2017). These dormancy and dispersal mechanisms can potentially provide an avenue of escape for seagrasses from other environmental stressors.

In some cases, when the environmental temperatures are too extreme, they can be deleterious (i.e. die-off: $1 \rightarrow 4$ in Fig. 3). Massive die-offs of seagrasses due to ocean warming, especially after MHWs, have been reported recently (Marbà \& Duarte, 2010; Arias-Ortiz et al., 2018; Strydom et al., 2020). Increased mortality due to warming has been observed in adult plants and also in seedlings (Olsen et al., 2012; Guerrero-Meseguer, Marín \& SanzLázaro, 2017; Hernán et al., 2017; Pereda-Briones, Terrados \& Tomas, 2019). After such massive mortality, in some cases seagrass meadows can recover naturally, although such recovery can take decades, especially for slow-growing species (O'Brien et al., 2018). For example, after the acute MHW that affected the coastline of Western Australia in the austral summer of 2010/2011, recovery of the seagrass Amphibolis antarctica was still partial 5 years post-MHW (Strydom et al., 2020) while no seed production was recorded in the disturbed P. australis meadow until 2016-2017 (Kendrick et al., 2019). Recurrent MHWs can further increase plant mortality in already impacted populations, hampering their recovery and jeopardizing their survival (Marbà \& Duarte, 2010). 
423 After a local extinction, the same seagrass population can potentially recolonize its former space by asexual reproduction (i.e. vegetative recruitment) of acclimatized/adapted plants, and/or by sexual reproduction through seed dispersal and seed dormancy (i.e. re-colonization: $4 \rightarrow 2$ in Fig. 3) (Diaz-Almela et al., 2007; Blok et al., 2018; Ruiz et al., 2018; Marín-Guirao et al., 2019). This phenomenon has been documented following physical disturbance (Olesen et al., 2004), warm-induced anoxia events (Plus, Deslous-Paoli \& Dagault, 2003), or microalgal blooms (Lee et al., 2007b). Importantly, while relatively slow-growing seagrasses [e.g. Thalassia hemprichii and Enhalus acoroides (Olesen et al., 2004) and Z. marina (Lee et al., 2007b; Plus et al., 2003)] tend to recolonize through sexual reproduction, faster-growing seagrasses [e.g. Cymodocea rotundata and H. uninervis (Olesen et al., 2004)], tend to undergo vegetative recolonization. Small- and medium-sized species often grow rapidly and can quickly re-occupy an area after heat stress.

On the other hand, the disappearance of local populations of seagrasses due to ocean warming can create an empty niche for colonization by new thermally tolerant species (new colonization: $4 \rightarrow 5$ in Fig. 3). The rapid expansion of the tropical seagrass $H$. stipulacea in the Mediterranean is an example of this phenomenon (Lipkin, 1975; Gambi, Barbieri \& Bianchi, 2009). Given that the invasive $H$. stipulacea has expanded rapidly throughout coastal areas of the Caribbean Sea within less than 20 years (Willette \& Ambrose, 2012; Steiner \& Willette, 2015), the distribution of this species in the Mediterranean has been predicted to accelerate in future (Georgiou et al., 2016; Beca-Carretero et al., 2020; Nguyen et al., 2020a).

Optimistically, new colonizations by thermally tolerant species could provide alternative ecosystem services, including carbon sinks (even if less successfully; e.g. H. stipulacea, see seagrasses (Apostolaki et al., 2019). 
447 Finally, in an era of rapid ocean change, the future of seagrasses is, indeed, difficult to forecast (i.e. $2 \rightarrow 4 \& 5 \rightarrow 4$ in Fig. 3). Although some thermal-adapted/thermal-tolerant seagrasses could potentially survive and even benefit from ocean warming in the near future (Saha et al., 2019; Nguyen et al., 2020a), the existence of these species/populations may be challenged due to the on-going increased frequency of extreme climatic events and humaninduced impacts on the marine environment (Ralph et al., 2007; Oliver et al., 2019). However, seagrass management and restoration could effectively contribute to sustaining these seagrasses and their services into the future (Ramesh et al., 2019; Valdez et al., 2020). Will warm-adapted/thermal-tolerant seagrasses survive future ocean change? To the best of our knowledge, an answer to this question remains open.

\section{(4) Effects of warming and seagrass responses at the ecosystem/planetary level}

Warming can switch seagrass ecosystems from autotrophic to heterotrophic (Burkholz, Duarte \& Garcias-Bonet, 2019) and enhance $\mathrm{CO}_{2}$ together with methane fluxes from meadows into the atmosphere (Burkholz, Garcias-Bonet \& Duarte, 2020), not only reducing the ability of this ecosystem to buffer climate warming, but also contributing to it (see Fig. 3). After the massive mortality of seagrasses in Shark Bay (Australia), substantial quantities of $\mathrm{CO}_{2}$ were released to the atmosphere, contributing to the greenhouse effect (Arias-Ortiz et al., 2018). A trophic transformation is not always the result of ocean warming, but will depend on seagrass species, co-occurring stressors (Macreadie \& Hardy, 2018), and sometimes the diversity of seagrass meadows (Burkholz et al., 2019). Warming threatens the distribution of large and long-lived species of seagrass [e.g. P. oceanica (Marbà \& Duarte, 2010; Jordà et al., 2012)], favouring the expansion of some small rapid-growing species [e.g. H. stipulacea (Georgiou et al., 2016; Nguyen et al., 2020a)]. Thus, warming is accelerating the tropicalization of temperate meadows (Hyndes et al., 2016). When the ecosystem 
472 functions of seagrasses depend strongly on their primary production (i.e. their biomass), a

473 switch from large species to small species due to warming could significantly reduce their

474 value in terms of ecosystem services as well as blue carbon storage (blue carbon is the carbon

475 stored in coastal and marine ecosystems).

476 Globally, seagrass meadows represent over $20 \%$ of nursery habitats for the 25 most important

477 fishery species (Unsworth et al., 2019). Therefore, loss of seagrass meadows negatively

478 impacts global fisheries, the economy, and coastal communities that rely on fishing for food

479 and employment (Tuya, Haroun \& Espino, 2014; Unsworth et al., 2019).

480 Worldwide, seagrasses protect coastlines from the impact of waves and storms (Guannel et $a l ., 2016)$. Nevertheless, it is important to note that the coastal defence service of seagrasses mostly depends on some large, long-lived species (e.g. Z. marina and P. oceanica). Warming threatens the existence of these species and enhances tropicalization with their replacement by small, seasonal species, which have a much lower capacity for coastal protection. Warming-induced seagrass declines can potentially alter neighbouring habitat-formers, such as corals (Bulleri et al., 2018). Where seagrasses grow alongside corals (e.g. Gulf of Aqaba, Israel; Winters et al., 2017), the disappearance of seagrasses has led to: (1) incremented sediment re-suspension and nutrients in the water column resulting in algal blooms (Genin, Lazar \& Brenner, 1995); (2) enhanced decalcification of corals as a consequence of increased ocean acidification (Hoegh-Guldberg et al., 2007); (3) a reduction in biodiversity as some reef fish feed in nearby seagrass meadows (Beck et al., 2001); and (4) increased prevalence of pathogens (Lamb et al., 2017). Warming, therefore, will not only affect seagrass habitats but also other nearby habitat-former species such as coral reefs. 
Under natural conditions, environmental stressors do not occur individually, but concurrently and synergistically (Sandifer \& Sutton-Grier, 2014). Hence, studying the interaction of ocean warming with other stressors is crucial for the comprehensive and precise understanding of seagrass responses to their changing environment (Gunderson, Armstrong \& Stillman, 2016).

\section{(a) Warming and salinity changes}

Changes in salinity are recognized as a major factor forcing the evolutionary trajectory of seagrasses, conditioning their distribution, ecology, and biology (Kuo \& Den Hartog, 2000). It is among the most challenging factors for seagrasses to tolerate (Olsen et al., 2016), as is also the case for terrestrial plants. Global warming causes ice melting and sea-level rise, and an increase in watershed runoff, reducing salinity in some areas (Nicholls \& Cazenave, 2010), but warmer temperatures are also increasing salinity in semi-isolated oceans such as the Mediterranean Sea (Borghini et al., 2014). Increased salinity in seagrass habitats can also occur as a consequence of brine discharge into coastal waters from desalination plants (Touchette, 2007). Seawater desalination is a growing industry in several regions that are now experiencing water scarcity (Lattemann \& Höpner, 2008); brine discharge can have a negative impact on seagrass populations (Ruíz, Marín-Guirao \& Sandoval-Gil, 2009; Sandoval-Gil et al., 2014). Generally, seagrasses are tolerant to a range of salinities. Nonetheless, increased seagrass mortality in response to warming is greater at low salinity levels (i.e. below 15 PSU) (Nejrup \& Pedersen, 2008; Kaldy \& Shafer, 2013; Collier et al., 2014; Salo \& Pedersen, 2014). Thus, the combined effects of ocean warming and salinity changes (especially lower salinity levels) is a concern.

The synergistic effects of salinity and temperature cannot be generalized among different species or populations. In fact, seagrass responses to stressors such as salinity changes depend on plasticity and local adaptation (Pazzaglia et al., 2021). Kaldy \& Shafer (2013) 
showed, for example, intraspecific differences between populations: northern Zostera japonica plants, which experienced a higher salinity range at Padilla Bay, were less resilient to heat stress than their counterparts growing at the southern limit of the species range (Coos Bay) that experienced a lower salinity range. Interspecific differences related to divergent responses to warming and salinity have been identified in the seagrass species Halophila ovalis, H. uninervis, and Z. muelleri (Collier et al., 2014). Moreover, the combined effects of temperature and salinity not only affects adult plants, but also induces mortality in seagrass seedlings, which can greatly influence the adaptation and resilience of seagrass meadows (Salo \& Pedersen, 2014).

(b) Warming and light limitation

One of the most widespread threats to seagrasses is light limitation due to anthropogenic activities. Changes in sedimentation regime, nutrient loading with subsequent algal blooms, and dredging all cause water turbidity (e.g. De Boer, 2007). Widespread seagrass die-off has been attributed to reduced water clarity (Walker \& McComb, 1992; Ralph et al., 2007).

Seagrasses can be distributed along wide depth gradients with different light regimes (in quality and quantity). The impact of thermal stress is likely to be more severe in plants under conditions in which there is light limitation (Collier et al., 2011; York et al., 2013; Kim et al., 2019). Having enough light for photosynthesis enables plants to maintain a positive energy/carbon balance when increased temperature enhances respiration. Thus under conditions of reduced light availability, seagrasses show reduced thermal tolerance and are more prone to suffer from heat stress during MHWs. For example, the Australian species $H$. uninervis and Z. muelleri require saturating light levels to respond positively to increasing temperatures (Collier et al., 2011). This highlights the importance of maintaining and improving water quality to enhance the resilience of seagrass to climate warming. The 
interactive effects of light and temperature have been shown to be weaker than for each factor separately, and temperature seems to play a dominant role in this combination (York et al., 2013; Kim et al., 2019). For P. oceanica, Hendriks et al. (2017) identified the roles of light and temperature to be far more critical to seagrass health than $\mathrm{CO}_{2}$ levels. In fact, the negative effects of ocean warming are forecast to outweigh any potentially positive effect of ocean acidification on some seagrass species (Zimmerman, Hill \& Gallegos, 2015; Repolho et al., 2017; Collier et al., 2018).

(c) Warming and sulphide stress

555

556

557

Sulphate reduction is a fundamental process that occurs in terrestrial water-saturated soils as well as marine sediments, where gas exchanges are very limited, resulting in the natural accumulation of sediment sulphide (Holmer \& Hasler-Sheetal, 2014). Generally, sulphide is toxic to living organisms including seagrasses, as it can strongly impact cellular enzymatic processes (Raven \& Scrimgeour, 1997). To survive in the highly toxic sulphide environment of marine sediments, seagrasses have developed sophisticated mechanisms to transport oxygen from the leaves into the rhizosphere to maintain an aerobic environment, protecting their tissues from the intrusion of sulphide (Borum et al., 2007). Warming can accelerate microbial activities, in turn increasing sulphate reduction, and consequently, sulphide concentration in the sediments (Frederiksen et al., 2007; Marbà et al., 2007). This phenomenon, when accompanied by warming, can enhance sulphide intrusion into seagrass tissue with the potential further to disrupt carbon metabolism and result in plant starvation and mortality (Robblee et al., 1991; Koch et al., 2007; Holmer \& Hasler-Sheetal, 2014). There is evidence that warming can enhance sulphide stress in seagrasses (Garcias-Bonet $e t$ al., 2008; García et al., 2012, 2013). Importantly, the sensitivity of seagrasses to the combined effects of warming and sulphide will be species specific (Koch et al., 2007) and 
571 depth specific (García et al., 2013). However, with on-going ocean warming, even deep

572 seagrasses are likely to be negatively impacted by sulphide stress in the future (García et al., 573 2013).

(d) Warming and eutrophication

576 The rapid development of agricultural activities across the globe has released huge nutrient

577 loads into rivers and coastal waters triggering eutrophication that leads to catastrophic consequences for sessile marine organisms (Rabalais, Harper \& Turner, 2001; Rabalais et al., 2009; Diaz \& Rosenberg, 2008). Nutrient enrichment also induces overgrowth of macroalgae, phytoplankton, and seagrass epiphytes, leading to light reduction and impacting seagrass growth and survival. Indeed, together with ocean warming, eutrophication is recognized as one of the main stressors to seagrasses globally [see reviews by Burkholder $e t$ al. (2007) and Lee et al. (2007a)]. Previous studies have demonstrated that the combined effect of warming and nutrient enrichment can vary. For instance, nutrient enrichment can accelerate the negative impact of warming on some seagrass species, such as Zostera capensis, C. nodosa and P. oceanica (Mvungi \& Pillay, 2019; Ontoria et al., 2019a,b). Pazzaglia et al. (2020) investigated the combined effects of warming and nutrient enrichment on different $P$. oceanica populations with different nutrient load histories. Plants growing in chronically eutrophic conditions were more prone to suffer from thermal stress than plants from populations living under oligotrophic/pristine conditions. Additionally, the accumulation of drift algae following an increase in seawater temperature and eutrophication may also affect seagrasses negatively. Drift algae are shallow-water unattached macroalgae that often bloom massively in eutrophication conditions and can deleteriously impact seagrass meadows (McGlathery, 2001). Holmer, Wirachwong \& Thomsen (2011) investigated the combined effects of drift algae and warming, showing that warming/nutrient- 
induced higher densities of drifting algae can additively and synergistically extend the negative impacts of warming on the seagrass species $H$. ovalis and suggesting that drift algae should be removed to protect seagrass meadows. By contrast, Egea et al. (2018) showed that the combination of warming, nutrient enrichment, and acidification could have positive effects on the seagrass $C$. nodosa, and thus predicted that this species could benefit from future ocean change. Interestingly, warming and nutrient enrichment could also reduce grazing pressure on seagrasses, as in the case of the sea urchin Amblypneustes pallidus on the seagrass A. antarctica (Burnell et al., 2013).

\section{(e) Warming and herbicides}

The increase in coastal agriculture activities has led to the runoff of large quantities of agricultural herbicides (e.g. diuron, atrazine, hexazinone, tebuthiuron and ametryn) into coastal marine environments (Smith et al., 2012). These herbicides can have a strong impact on PSII of seagrasses, not only damaging seagrass performance but also increasing their susceptibility to other stressors (Flores et al., 2013; Negri et al., 2015; Wilkinson et al., 2015). To date, only one study has investigated the combined effects of warming and a herbicides (diuron), which showed strong antagonistic effects of combined stressors on the tropical seagrass species H. ovalis (Wilkinson et al., 2017).

The impact of herbicides on seagrasses thus will become a greater concern with ocean warming. Additionally, we note that most studies investigating the effects of herbicides on seagrass species targeted the Great Barrier Reef area (Lewis et al., 2009; Flores et al., 2013; Negri et al., 2015; Wilkinson et al., 2015, 2017). Globally, the use of herbicide-resistant genetically modified (GM) crops is still controversial, thus conventional agricultural production remains dependent on herbicides to control weeds (Green, 2014). Consequently, herbicides still pose a great potential risk for seagrasses across the globe, and future studies to 
understand the effects of herbicides on seagrasses from other regions of the world are highly encouraged.

\section{(f) Warming and pathogens}

Massive losses of seagrass meadows have been documented across the globe after outbreaks of seagrass diseases (see review by Sullivan et al., 2018). Human-induced environmental changes, especially ocean warming, can enhance the susceptibility of seagrasses to these biotic threats by promoting the development of seagrass diseases and reducing their resilience (Burge \& Hershberger, 2020; Sullivan et al., 2018). 'Wasting disease', caused by the protist Labyrinthula sp., is the best studied example in seagrasses [e.g. Phytophthora gemini and Halophytophthora zostera (reviewed by Sullivan et al., 2018)]. There was a wasting disease epidemic in the seagrass Z. marina along the Atlantic coasts of North America and Europe during the 1930s, causing the extinction of as much as $90 \%$ of the total Z. marina population, and leading to profound ecological impacts within the coastal ecosystem (Renn, 1936).

Nevertheless, experimental studies have also shown that an increase in ocean temperature may limit infections of seagrass diseases. For example, recent studies on two Mediterranean seagrass species, $P$. oceanica and $C$. nodosa, suggested that temperatures above $28^{\circ} \mathrm{C}$ inhibit the growth of Labyrinthula sp., thus reducing the pathogenic pressure on this seagrass (Olsen et al., 2014; Olsen \& Duarte, 2015). In addition, Brakel et al. (2019) tested the effect of this protist on Z. marina in a predicted scenario with a combination of heat stress, light limitation, and different salinity levels, confirming the predicted reduction in pathogen pressure on seagrasses in response to predicted future warming. These results provide a more optimistic view about the future of seagrasses, particularly in the context of seagrass-pathogen dynamics. However, note that ocean warming may facilitate the presence and virulence of other marine diseases (both viruses and bacteria) (Burge \& Hershberger, 2020). Given that 
there remain few studies on this topic and that seagrass diseases remain virtually unexplored [see review by Sullivan et al. (2018) for examples of other diseases in seagrasses], we recommend that future studies should attempt to broaden our understanding of the relationship between warming and pathogens in seagrasses.

\section{(g) Warming and herbivores}

The plant-herbivore interaction is fundamental for both parties not only from an evolutionary point of view (Fritz \& Simms, 1992), but also from its role in sustaining ecosystem dynamics (Bakker et al., 2016). In the presence of ocean warming, increases in seawater temperature will affect seagrasses and their herbivores not only individually, but also interactively. In general, warming increases the metabolic rate of herbivores, consequently enhancing grazing pressure (Hillebrand et al., 2009). Nevertheless, studies on the interactions of seagrasses with herbivores in response to temperature changes revealed a complex situation (Burnell et al., 2013; Garthwin, Poore \& Vergés, 2014; Pagès et al., 2018; Buñuel et al., 2021; GuerreroMeseguer, Marín \& Sanz-Lázaro, 2020). Pagès et al. (2018) studied the sea urchin Paracentrotus lividus that, in some cases [e.g. P. oceanica beds on the northeast Spanish coast and in the south of France (Prado et al., 2007)], consumes about $17 \%$ of seagrass production annually, showing that warming could weaken herbivore pressure on two Mediterranean seagrass species, . oceanica and C. nodosa (Pagès et al., 2018). By contrast, Burnell et al. (2013) showed that a temperature increase could enhance grazing pressure of Amblypneustes pallidus on the seagrass A. antarctica; however, nutrient enrichment was shown to reduce grazing pressure in combination with ocean warming and acidification. Similarly, a recent study on $P$. oceanica and its main fish herbivore Sarpa salpa demonstrated that warming can make the seagrass more palatable, increasing the growth rate of the fish (especially in the larval stage), and thus potentially intensifying herbivory pressure 
671 (Buñuel et al., 2021). The combined effects of warming and herbivores also affect seagrass 672 seedlings: Guerrero-Meseguer et al. (2020) found that the combined effects of MHWs and overgrazing led to a greater reduction in leaf growth and increased leaf senescence of $P$. oceanica seedlings in comparison with the effects of each factor alone. The authors suggested that the combined effects of ocean warming and other stressors are likely to threaten the survival of $P$. oceanica seedlings, and consequently sexual recruitment (Guerrero-Meseguer et al., 2020). By contrast, Garthwin et al. (2014) conducted a simulated herbivory experiment on a Zostera muelleri meadow warmed by the thermal plume from a power station for 30 years and three nearby control meadows. Their results demonstrated that the ability of $Z$. muelleri to tolerate herbivory is not strongly affected by warming. The future of seagrassherbivore interactions in an era of ocean warming still remains unclear and deserves additional attention in future studies.

\section{FUTURE PERSPECTIVES}

Seagrasses are facing a critical time in their evolutionary history in which their continued existence will depend on our actions, including research, restoration, and management activities. Below, we discuss some significant gaps in knowledge and recommend future directions for seagrass studies.

\section{(1) Enlarging the number of species and populations studied}

Previous studies have shown that the effects of ocean warming are not the same for all seagrass species and populations. Therefore, it remains difficult to predict the future of seagrasses accurately. Most seagrass studies in the context of ocean warming come from three regions: the Mediterranean Sea, USA, and Australia (Fig. 4, see online Supporting Information Table S1). Most of these studies have focused on only a few seagrass species: $Z$. 
marina, P. oceanica and C. nodosa (Table S2). This highlights a significant gap in our understanding of how warming affects seagrasses; the vast majority of the world's seagrass species have not been studied in this context to date. Future studies should focus not only on additional species but also on more populations within each species to deliver a more comprehensive picture of how seagrasses will respond to a future changing climate.

Since warming potentially interacts with many other stress factors, seagrass meadows are currently under multiple anthropogenic pressures. Populations that are chronically stressed (e.g. under eutrophic conditions) might have a different tolerance or ability to respond to warming compared to healthy populations. There is an urgent need to explore how responses to warming differ between healthy and chronically stressed populations. This knowledge will be critical for improving the management and protection of valuable seagrass ecosystems by managing local factors that directly affect seagrass health, potentially enhancing their resilience to warming.

\section{(2) Developing more precise and detailed seagrass distribution maps}

Some seagrass species are losing habitat at a rapid rate (Robblee et al., 1991; Seddon et al., 2000; Jordà et al., 2012; Marbà, Díaz-Almela \& Duarte, 2014) or are being replaced by the rapid expansion of other species (Gambi et al., 2009; Scheibling, Patriquin, \& Filbee-Dexter, 2018; Nguyen et al., 2020a). Studies (Short et al., 2007; Jayathilake \& Costello, 2018) have provided general information regarding seagrass distribution, but there are many regions that remain unmapped (Assis et al., 2020; McKenzie et al., 2020). Building seagrass distribution maps can be challenging, especially for species that have a wide distribution range with different depths or inhabit mixed-species meadows. Effective methods have been developed to map seagrasses (see review by McKenzie, Finkbeiner \& Kirkman, 2001) and more recently, a low-cost field-survey method using snorkelling and perpendicular transects 
721 (Winters et al., 2017) was developed at a small regional scale. Advanced technologies [e.g.

722

satellite remote sensing, Geographic Information System (GIS) technologies, cameraequipped drones] have also been employed in seagrass mapping research (Barrell et al., 2015; Phinn et al., 2018). Future work is encouraged both in developing advanced technologies and in building more detailed seagrass maps across different regions of the world.

\section{(3) Long-term monitoring programs}

Many countries across the globe have implemented seagrass long-term monitoring networks appropriate to their local species and habitats. Since the end of the 20th century, many monitoring programs have been aggregating data to create regional and/or global monitoring networks with the aim to preserve seagrass meadows and to increase scientific knowledge and public awareness about these threatened and valuable ecosystems. At the global level, Seagrass-Watch (http://www.seagrasswatch.org/) and SeagrassNet (http://www.seagrassnet.org/) integrate hundreds of sites distributed along the coasts of dozens of countries for the long-term ecological monitoring of seagrasses. In the Mediterranean, the regional integration of existing networks is lacking, but initiatives are currently ongoing, for instance the POSIMED project (http://posimed.org/).

Data from long-term seagrass monitoring programs are not only providing valuable information to unravel the status and trends of natural populations at the global, regional, and local scales (e.g. Thomas, Unsworth \& Rasheed, 2010; Rasheed \& Unsworth, 2011; de los Santos et al., 2019), but they are also helping in the development and execution of international environmental protection policies (e.g. the Marine Strategy European Directive). Seagrass monitoring programs are also recording environmental data, including water temperature, to correlate seagrass decline with warming trends or extreme warming events (Marbà \& Duarte, 2010; Richardson et al., 2018; Shields, Parrish \& Moore, 2019). 
However, ecosystem modelling and forecasting activities for seagrasses are still needed. This

747 could be facilitated by bridging global and local observations, and by linking long-term data series from seagrass monitoring programs to the continuous recording of coastal environmental conditions. Currently, platforms and sensor systems to measure physical, chemical, geological, and biological properties are increasingly being installed in coastal areas and oceanic regions worldwide [e.g. GOOS (https://www.goosocean.org/) and OOI (https://oceanobservatories.org/)]. The production of high-throughput data from multidisciplinary studies is a promising advance towards improving all aspects of seagrass conservation, from dynamic model development to forecast validation. These are powerful holistic approaches to monitoring seagrass ecosystems and their evolution in a rapidly changing ocean, as well as to contribute to their effective conservation and to the management of human activities in coastal areas (Capotondi et al., 2019). The integration of time-series data through multivariate statistics and/or machine-learning algorithms could also provide promising tools to monitor coastal ecosystems in a changing climate (Danovaro et al., 2016; Crise et al., 2018).

\section{(4) More realistic experiments in controlled conditions}

Many past studies suffered from experimental constraints/limitations such as using unrealistic temperature levels, warming rates, experimental duration, small water volumes, or even single seagrass shoots that prevented clonal integration (Bulthuis, 1987; Lee et al., 2007a). By contrast, recent experiments have become more realistic due to the development of sophisticated mesocosm systems for the culture of seagrasses in optimal conditions, and their use to conduct finely tuned and highly controlled experiments (Bergmann et al., 2010; MarínGuirao et al., 2011; Georgiou et al., 2016; Cambridge et al., 2017; Oscar, Barak \& Winters, 2018; Ruocco et al., 2019b). These new systems have enabled more robust experiments to 
obtain not only a significant amount of knowledge in a short period but also novel results (Bulthuis, 1987; Lee et al., 2007a). In the near future, the application of more advanced technologies are expected to push the boundary of seagrass research even further by enabling in situ experiments (e.g. Egea et al., 2019) and near-natural simulated environment experiments (e.g. Saha et al., 2019).

\section{(5) The study of the holobiont}

There is now an increasing recognition of the fundamental interactions between symbiotic microorganisms (bacteria, fungi, and archaea) and their host organisms. From both an ecological and evolutionary point of view, we should perhaps consider the organisms and their symbiotic microorganisms not separately but together. The term 'holobiont' has been used to describe this combination of the host organism and its microbiome (Vandenkoornhuyse et al., 2015). In terrestrial plants, the number of studies considering the holobiont has increased, uncovering important functions of the microbiome in plant nutrition, resistance to biotic and abiotic stresses, and evolution (Vandenkoornhuyse et al., 2015). In marine environments, interactions across holobionts are expected to be more flexible, with faster microbial community shifts, and greater phylogenetic diversity compared to terrestrial ecosystems (Dittami et al., 2021). Compared with terrestrial plants, the importance of the holobionts in marine ecosystems is understudied. Some pivotal investigations of seagrassbacteria interactions have suggested many important roles in providing nutrients, sustaining fitness, enhancing growth, and protecting seagrasses from toxic compounds and pathogens [see reviews by Ugarelli et al. (2017), Tarquinio et al. (2019) and Conte et al. (2021)]. In the face of ocean warming, the activity of the seagrass-bacterial community in relation to carbon remineralization is expected to increase, consequently reducing carbon accumulation rates in seagrass meadows (Trevathan-Tackett et al., 2017). Future studies of the seagrass holobiont 
should focus on a better understanding of (1) the components of the seagrass microbiome, (2)

797

798

799

800

801

802

803

804

805

806

807

808

809

810

811

812

813

814

815

816

817

818

seagrass-microbiome interactions in an ecological context, and especially (3) how the

seagrass microbiome can help seagrasses to be more resilient to environmental changes. Such studies will not only broaden our understanding of this important aspect of seagrass ecology but will also be extremely useful for seagrass restoration activities, as symbiotic microorganisms could potentially be used to enhance the survival of transplanted seagrasses (both seedlings and adult plants).

\section{(6) Seagrasses as a solution to mitigate climate change}

Adopting the concept of Gattuso et al. (2018) that ocean solutions may allow us to address climate change, it is essential to restore and conserve healthy seagrass meadows worldwide in order to preserve the ecosystem services that they provide in mitigating climate change and its associated effects. In the agriculture and food industries, the application of genetic engineering has significantly improved the productivity and quality of crops and commercial species (see review by Janni et al., 2020). To the best of our knowledge, such approaches (e.g. CRISPR/Cas9 which is short for clustered regularly interspaced short palindromic repeats and CRISPR-associated protein 9) have never been applied in seagrass research. This novel approach provides a promising way to select, breed, or produce genotypes that can survive future harsh environmental conditions (i.e. assisted evolution; see also Bulleri et al., 2018). Such potential super-seagrasses could help us to re-establish ecosystems in areas where seagrasses have been completely destroyed due to natural and/or human-induced catastrophic events. Additionally, as seagrasses growing in extreme environments (e.g. under anthropogenic pressures, frequent MHWs, etc.) are expected to be more resilient to ocean warming, transplantations performed using such selected plants could be extremely useful in seagrass restoration (see review by Tan et al., 2020). Moreover, emerging knowledge in the 
field of thermal stress memory and epigenetic memory in seagrasses (Jueterbock et al., 2020;

822

823

824

Nguyen et al., 2020b) could yield in many potential applications in seagrass restoration.

Together, the application of such new approaches could support attempts to restore degraded seagrass meadows effectively and sustainably at a global scale and consequently protect their ecosystem services (Reynolds et al., 2016b), thus ultimately mitigating the negative impacts of climate change.

\section{CONCLUSIONS}

(1) Warming strongly affects seagrasses at all levels from molecular, physiological, biochemical, morphological, and population to planetary level.

(2) Seagrass responses to warming vary amongst species, populations, and depths.

(3) Warming causes massive die-offs, tropicalization, and migration in seagrasses.

(4) Multiple-stressor studies in seagrasses are much needed to provide deeper insights into seagrass resilience, especially in an era of ocean warming.

(5) Significant knowledge gaps and future directions for seagrass research include: (i) studies involving additional species and populations; (ii) development of more precise and detailed seagrass distribution maps; (iii) more long-term monitoring programs; (iv) more realistic experiments in controlled conditions; $(v)$ investigation of the seagrass holobiont; and (vi) seagrasses as a solution to mitigate climate change.

\section{ACKNOWLEDGMENTS}

H.M.N. was supported by an SZN Ph.D. fellowship via the Open University. The work was partially supported by the project Marine Hazard (Ministero dell'Istruzione, dell'Università e della Ricerca, Italy, Grant/Award Number: PON03PE_00203_1) and by the project EpicSea (SZN, Progetti per la Ricerca Internazionale Extra EU). The authors would like to thank an 
anonymous reviewer for many constructive comments and suggestions.

847

\section{REFERENCES}

849

850

851

852

853

854

855

856

857

858

859

860

861

862

863

864

865

866

867

868

869

870

AllakhVerdiev, S.I., Kreslavski, V.D., Klimov, V. V., Los, D.A., CARPENTIER, R. \& MOHANTY, P. (2008). Heat stress: an overview of molecular responses in photosynthesis. Photosynthesis Research 98, 541-550.

ANDERSON, T.R., HAWKInS, E. \& JONES, P.D. (2016). $\mathrm{CO}_{2}$, the greenhouse effect and global warming: from the pioneering work of Arrhenius and Callendar to today's Earth System Models. Endeavour 40, 178-187.

Apostolaki, E.T., Vizzini, S., Santinelli, V., Kaberi, H., Andolina, C. \& Papathanassiou, E. (2019). Exotic Halophila stipulacea is an introduced carbon sink for the Eastern Mediterranean Sea. Scientific Reports 9, 9643.

Arias-Ortiz, A., Serrano, O., Masqué, P., Lavery, P.S., Mueller, U., Kendrick, G.A., Rozaimi, M., Esteban, A., Fourqurean, J.W., MarbÀ, N., Mateo, M.A., Murray, K., Rule, M.J. \& DuARTE, C.M. (2018). A marine heatwave drives massive losses from the world's largest seagrass carbon stocks. Nature Climate Change 8, 1-7.

Dittami, S.M., Arboleda, E., Auguet, J., Bigalke, A., Briand, E., Cardenas, P., Cardini, U., Decelle, J., Engelen, A.H., Eveillard, D., Gachon, C.M.M., GrifFiths, S.M., HARder, T., KAYAL, E., KAZAMIA, E., ET AL. (2021). A community perspective on the concept of marine holobionts: current status, challenges, and future directions. PeerJ 9, e10911.

Assis, J., Fragkopoulou, E., Frade, D., Neiva, J., Oliveira, A., Abecasis, D., Faugeron, S. \& SERRÃO, E.A. (2020). A fine-tuned global distribution dataset of marine forests. Scientific Data 7, 119.

BAKKer, E.S., WoOd, K.A., PAGÈs, J.F., Veen, G.F.C., Christianen, M.J.A., SANTAMaría, 
L., NOLET, B.A. \& HILT, S. (2016). Herbivory on freshwater and marine macrophytes: a review and perspective. Aquatic Botany 135, 18-36.

873

874

BARBER, B.J. \& BEHRENS, P.J. (1985). Effects of elevated temperature on seasonal in situ leaf productivity of Thalassia testudinum Banks ex König and Syringodium filiforme Kützing. Aquatic Botany 22, 61-69.

BARrell, J., Grant, J., HANSON, A. \& MAHONEY, M. (2015). Evaluating the complementarity of acoustic and satellite remote sensing for seagrass landscape mapping. International Journal of Remote Sensing 36, 4069-4094.

BARshis, D.J., LAdner, J.T., Oliver, T.A., SeneCA, F.O., Traylor-KnOWles, N. \& PALUMBI, S.R. (2013). Genomic basis for coral resilience to climate change. Proceedings of the National Academy of Sciences of the United States of America 110, $1387-1392$.

Bech-Carretero, P., Olesen, B., Marbà, N. \& Krause-Jensen, D. (2018a). Response to experimental warming in northern eelgrass populations: comparison across a range of temperature adaptations. Marine Ecology Progress Series 589, 59-72.

Beca-Carretero, P., Guiténeuf, F., Marín-Guirao, L., Bernardeau-Esteller, J., GARCÍA-MuÑoz, R., STEngel, D.B. \& RuIZ, J.M. (2018b). Effects of an experimental heat wave on fatty acid composition in two Mediterranean seagrass species. Marine Pollution Bulletin 134, 27-37.

Beca-Carretero, P., Teichberg, M., Winters, G., Procaccini, G. \& Reuter, H. (2020). Projected rapid habitat expansion of tropical seagrass species in the mediterranean sea as climate change progresses. Frontiers in Plant Science 11, 1762.

Beck, M.W., Heck, K.L., Able, K.W., Childers, D.L., Eggleston, D.B., Gillanders, B.M., HalPern, B., Hays, C.G., Hoshino, K., Minello, T.J., ORTH, R.J., ShediRAn, P.F. \& WEINSTEIN, M.P. (2001). The Identification, Conservation, and Management of 
Estuarine and Marine Nurseries for Fish and Invertebrates: A better understanding of the

897

898

899

900

901

902

903

904

905

906

907

908

909

910

911

912

913

914

915

916

917

918

919

920 habitats that serve as nurseries for marine species and the factors that create site-specific variability in nursery quality will improve conservation and management of these areas. BioScience 51, 633-641.

BEERE, H.M. (2005). Death versus survival: Functional interaction between the apoptotic and stress-inducible heat shock protein pathways. Journal of Clinical Investigation 115, 2633-2639.

Bergmann, N., Winters, G., Rauch, G., Eizaguirre, C., Gu, J., Nelle, P., Fricke, B. \& REUSCH, T.B.H. (2010). Population-specificity of heat stress gene induction in northern and southern eelgrass Zostera marina populations under simulated global warming. Molecular Ecology 19, 2870-2883.

Bertelli, C.M. \& Unsworth, R.K.F. (2014). Protecting the hand that feeds us: Seagrass (Zostera marina) serves as commercial juvenile fish habitat. Marine Pollution Bulletin 83, 425-429.

BloK, S.E., Olesen, B. \& KrAUSE-JENSEN, D. (2018). Life history events of eelgrass Zostera marina L. populations across gradients of latitude and temperature. Marine Ecology Progress Series 590, 79-93.

Borghini, M., Bryden, H., Schroeder, K., Sparnocchia, S. \& Vetrano, A. (2014). The Mediterranean is getting saltier. Ocean Science Discussions 11, 735-752.

Borum, J., Sand-Jensen, K., Binzer, T., Pedersen, O. \& Greve, T.M. (2007). Oxygen movement in seagrasses. In Seagrasses: biology, ecologyand conservation, pp. 255-270. Springer.

Bossdorf, O., Richards, C.L. \& PigliucCI, M. (2008). Epigenetics for ecologists. Ecology Letters 11, 106-115.

BraKel, J., JAKOBSSON-ThOR, S., BockelmanN, A.C. \& ReusCH, T.B.H. (2019). 
Modulation of the Eelgrass - Labyrinthula zosterae Interaction Under Predicted Ocean Warming, Salinity Change and Light Limitation. Frontiers in Marine Science 6, 268.

923

Bulleri, F., Eriksson, B.K., QueIrós, A., Airoldi, L., ArenAs, F., Arvanitidis, C., Bouma, T.J., Crowe, T.P., Davoult, D., GuIZIEN, K., IveŠA, L., Jenkins, S.R., Michalet, R., Olabarria, C., Procaccini, G., et AL. (2018). Harnessing positive species interactions as a tool against climate-driven loss of coastal biodiversity. PLoS Biology 16, e2006852.

Bulthuis, D.A. (1987). Effects of temperature on photosynthesis and growth of seagrasses. Aquatic Botany 27, 27-40.

Buñuel, X., Alcoverro, T., Romero, J., Arthur, R., Ruiz, J.M., Pérez, M., Ontoria, Y., RAVENTÓs, N., MACPHERSON, E. \& TORRADO, H. (2021). Warming intensifies the interaction between the temperate seagrass Posidonia oceanica and its dominant fish herbivore Sarpa salpa. Marine Environmental Research 165, 105237.

Burge, C.A. \& Hershberger, P.K. (2020). Climate change can drive marine diseases. In Marine Disease Ecology, pp. 83. Oxford University Press, USA.

Burkholder, J.M., Tomasko, D.A. \& Touchette, B.W. (2007). Seagrasses and eutrophication. Journal of Experimental Marine Biology and Ecology 350, 46-72.

Burkholz, C., Duarte, C.M. \& Garcias-Bonet, N. (2019). Thermal dependence of seagrass ecosystem metabolism in the Red Sea. Marine Ecology Progress Series 614, 79-90.

Burkholz, C., Garcias-Bonet, N. \& DuARTe, C.M. (2020). Warming enhances carbon dioxide and methane fluxes from Red Sea seagrass (Halophila stipulacea) sediments. Biogeosciences 17, 1717-1730.

Burnell, O.W., Russell, B.D., IRVING, A.D. \& ConNell, S.D. (2013). Eutrophication offsets increased sea urchin grazing on seagrass caused by ocean warming and 

acidification. Marine Ecology Progress Series 485, 37-46.

Cambridge, M.L., Zavala-Perez, A., Cawthray, G.R., Mondon, J. \& Kendrick, G.A. (2017). Effects of high salinity from desalination brine on growth, photosynthesis, water relations and osmolyte concentrations of seagrass Posidonia australis. Marine Pollution

CAMPBell, S.J., McKenZIE, L.J. \& KeRVILle, S.P. (2006). Photosynthetic responses of seven tropical seagrasses to elevated seawater temperature. Journal of Experimental Marine Biology and Ecology 330, 455-468.

Capotondi, A., Jacox, M., Bowler, C., Kavanaugh, M., Lehodey, P., Barrie, D., Brodie, S., ChafFron, S., Cheng, W. \& DiAs, D.F. (2019). Observational Needs Supporting Marine Ecosystems Modeling and Forecasting: From the Global Ocean to Regional and Coastal Systems. Frontiers in Marine Science 6, 623.

Ceccherelli, G., Oliva, S., Pinna, S., Piazzi, L., Procaccini, G., Marín-Guirao, L., Dattolo, E., Gallia, R., La Manna, G., Gennaro, P., Costa, M.M., Barrote, I.,

Chefaoui, R.M., Duarte, C.M. \& SERrão, E.A. (2018). Dramatic loss of seagrass habitat under projected climate change in the Mediterranean Sea. Global Change Biology 24, $4919-4928$.

ChInNUSAMY, V. \& ZHU, J.-K. (2009). Epigenetic regulation of stress responses in plants.

Christidis, N., Jones, G.S. \& StotT, P.A. (2015). Dramatically increasing chance of extremely hot summers since the 2003 European heatwave. Nature Climate Change 5, 46-50.

Collier, C.J., Langlois, L., Ow, Y., Johansson, C., Giammusso, M., Adams, M.P., 
O’BRIEN, K.R. \& UTHICKE, S. (2018). Losing a winner: thermal stress and local pressures outweigh the positive effects of ocean acidification for tropical seagrasses. New Phytologist 219, 1005-1017.

Collier, C.J., Ow, Y.X., LAnglois, L., Uthicke, S., Johansson, C.L., O’Brien, K.R., HREBIEN, V. \& ADAMS, M.P. (2017). Optimum temperatures for net primary productivity of three tropical seagrass species. Frontiers in plant science 8, 1446.

Collier, C.J., Uthicke, S. \& WAycotT, M. (2011). Thermal tolerance of two seagrass species at contrasting light levels: Implications for future distribution in the Great Barrier Reef. Limnology and Oceanography 56, 2200-2210.

Collier, C.J., Villacorta-Rath, C., TAKahashi, M. \& WAycott, M. (2014). Seagrass proliferation precedes mortality during hypo-salinity events: a stress-induced morphometric response. PLoS One 9, e94014.

COLLIER, C.J. \& WAyCotT, M. (2014). Temperature extremes reduce seagrass growth and induce mortality. Marine Pollution Bulletin 83, 483-490.

Coma, R., Ribes, M., Serrano, E., Jimé Nez, E., SAlat, J. \& PAscual, J. (2009). Global warming-enhanced stratification and mass mortality events in the Mediterranean. Proceedings of the National Academy of Sciences of the United States of America 106, 6176-6181.

Conte, C., Rotini, A., Manfra, L., D’Andrea, M.M., Winters, G. \& Migliore, L. (2021).

Costanza, R., DE Groot, R., Sutton, P., van Der Ploeg, S., Anderson, S.J., KubiszewsKi, I., FARBER, S. \& TURNER, R.K. (2014). Changes in the global value of ecosystem services. Global Environmental Change 26, 152-158.

Crise, A., Ribera D’Alcalà, M., Mariani, P., Petihakis, G., Robidart, J., Iudicone, D., 
BACHMAYER, R. \& MALFATTI, F. (2018). A conceptual framework for developing the next generation of Marine OBservatories (MOBs) for science and society. Frontiers in Marine Science 5, 318.

Danovaro, R., Carugati, L., Berzano, M., Cahill, A.E., Carvalho, S., Chenuil, A., Corinaldesi, C., CRistina, S., DAVID, R. \& Dell'AnNO, A. (2016). Implementing and innovating marine monitoring approaches for assessing marine environmental status. Frontiers in Marine Science 3, 213.

Davey, P.A., Pernice, M., SAblok, G., Larkum, A., Lee, H.T., Golicz, A., Edwards, D., DOLFERUS, R. \& RALPH, P. (2016). The emergence of molecular profiling and omics techniques in seagrass biology; furthering our understanding of seagrasses. Functional and Integrative Genomics 16, 465-480.

1007

DE BOER, W.F. (2007). Seagrass-sediment interactions, positive feedbacks and critical thresholds for occurrence: a review. Hydrobiologia 591, 5-24.

de los Santos, C.B., Krause-Jensen, D., Alcoverro, T., Marbà, N., Duarte, C.M., van

KATwiJK, M.M., PÉrez, M., Romero, J., SÁnCheZ-LiZASO, J.L., RoCA, G., JANKOWsKA, E., PÉreZ-Lloréns, J.L., Fournier, J., Montefalcone, M., Pergent, G., Et al. (2019).

DiAZ, R.J. \& RoSEnBERG, R. (2008). Spreading dead zones and consequences for marine ecosystems. Science 321, 926-929.

Duarte, B., Martins, I., Rosa, R., Matos, A.R., Roleda, M.Y., Reusch, T., Engelen, 1020 
impacts on seagrass meadows and macroalgal forests: an integrative perspective on acclimation and adaptation potential. Frontiers in Marine Science 5, 190.

Easterling, D.R., Meehl, G.A., Parmesan, C., Changnon, S.A., Karl, T.R. \& Mearns, L.O. (2000). Climate extremes: Observations, modeling, and impacts. Science 289, 2068-2074.

EgeA, L.G., JimÉneZ-RAmos, R., Vergara, J.J., HeRnÁndeZ, I. \& BRUn, F.G. (2018). Interactive effect of temperature, acidification and ammonium enrichment on the seagrass Cymodocea nodosa. Marine Pollution Bulletin 134, 14-26.

EgEA, L.G., JimÉnEZ-RAMOs, R., HERnÁNDEZ, I. \& BRUn, F.G. (2019). Effect of in situ short-term temperature increase on carbon metabolism and dissolved organic carbon (DOC) fluxes in a community dominated by the seagrass Cymodocea nodosa. PLoS One 14, e0210386.

EHLERS, A., WORM, B. \& REUSCH, T.B.H. (2008). Importance of genetic diversity in eelgrass Zostera marina for its resilience to global warming. Marine Ecology Progress Series $355,1-7$.

Evans, A.S., WebB, K.L. \& Penhale, P.A. (1986). Photosynthetic temperature acclimation in two coexisting seagrasses, Zostera marina L. and Ruppia maritima L. Aquatic Botany 24, 185-197.

FENG, S. \& JACOBSEN, S.E. (2011). Epigenetic modifications in plants: An evolutionary perspective. Current Opinion in Plant Biology 14, 179-186.

Flores, F., Collier, C.J., Mercurio, P. \& Negri, A.P. (2013). Phytotoxicity of four photosystem II herbicides to tropical seagrasses. PloS One 8, e75798.

Fourqurean, J.W., Duarte, C.M., Kennedy, H., MarbÀ, N., Holmer, M., MateO, M.A., Apostolaki, E.T., Kendrick, G.A., Krause-Jensen, D. \& MCGlathery, K.J. (2012). Seagrass ecosystems as a globally significant carbon stock. Nature Geoscience 5, 505- 
509.

1047

1048

1049

1050

1051

1052

1053

1054

1055

1056

1057

1058

1059

1060

1061

1062

1063

1064

1065

1066

1067

1068

1069

1070

Franssen, S.U., Gu, J., Bergmann, N., Winters, G., Klostermeier, U.C., Rosenstiel, P., BORNBERG-BAUER, E. \& REUSCH, T.B.H. (2011). Transcriptomic resilience to global warming in the seagrass Zostera marina, a marine foundation species. Proceedings of the National Academy of Sciences 108, 19276-19281.

Franssen, S.U., Gu, J., Winters, G., HuYlmans, A.-K., WienPahl, I., SParwel, M., Coyer, J.A., Olsen, J.L., Reusch, T.B.H. \& BornBerG-BAuer, E. (2014). Genomewide transcriptomic responses of the seagrasses Zostera marina and Nanozostera noltii under a simulated heatwave confirm functional types. Marine Genomics 15, 65-73.

Frederiksen, M.S., Holmer, M., Díaz-Almela, E., Marba, N. \& Duarte, C.M. (2007). Sulfide invasion in the seagrass Posidonia oceanica at Mediterranean fish farms: assessment using stable sulfur isotopes. Marine Ecology Progress Series 345, 93-104.

FRITZ, R.S. \& SiMMS, E.L. (1992). Plant resistance to herbivores and pathogens: ecology, evolution, and genetics. University of Chicago Press.

GAMBI, M.C., BARBIERI, F. \& BIANCHI, C.N. (2009). New record of the alien seagrass Halophila stipulacea (Hydrocharitaceae) in the western Mediterranean: a further clue to changing Mediterranean Sea biogeography. Marine Biodiversity Records 2, e84.

García, R., Holmer, M., DuARTE, C.M. \& MARBÀ, N. (2013). Global warming enhances sulphide stress in a key seagrass species (NW Mediterranean). Global Change Biology 19, 3629-3639.

García, R., SÁNCheZ-CAMAChO, M., DuARTe, C.M. \& MARbÀ, N. (2012). Warming enhances sulphide stress of Mediterranean seagrass (Posidonia oceanica). Estuarine, Coastal and Shelf Science 113, 240-247.

Garcias-Bonet, N., MarbÀ, N., Holmer, M. \& Duarte, C.M. (2008). Effects of sediment sulfides on seagrass Posidonia oceanica meristematic activity. Marine Ecology 
Garthwin, R.G., PoOre, A.G.B. \& VErgés, A. (2014). Seagrass tolerance to herbivory under increased ocean temperatures. Marine Pollution Bulletin 83, 475-482.

Gattuso, J.-P., Magnan, A.K., BopP, L., Cheung, W.W.L., DuARTe, C.M., Hinkel, J., Mcleod, E., Micheli, F., Oschlies, A., Williamson, P., Billé, R., Chalastani, V.I., GATES, R.D., IriSSON, J.-O., MidDELBURG, J.J., ET AL. (2018). Ocean Solutions to Address Climate Change and Its Effects on Marine Ecosystems. Frontiers in Marine Science 5, 337.

GAUR, R.K. \& SHARMA, P. (2014). Approaches to plant stress and their management. Springer.

Genin, A., LAZAR, B. \& BRENNER, S. (1995). Vertical mixing and coral death in the Red Sea following the eruption of Mount Pinatubo. Nature 377, 507-510. 4517.

1087

George, R., Gullstrom, M., Mangora, M.M., Mtolera, M.S. \& BJork, M. (2018). High midday temperature stress has stronger effects on biomass than on photosynthesis: a mesocosm experiment on four tropical seagrass species. Ecology and Evolution 8, 4508-

Georgiou, D., Alexandre, A., Luis, J. \& Santos, R. (2016). Temperature is not a limiting factor for the expansion of Halophila stipulacea throughout the Mediterranean Sea. Marine Ecology Progress Series 544, 159-167.

GLEASON, L.U. \& BURTON, R.S. (2015). RNA-seq reveals regional differences in transcriptome response to heat stress in the marine snail Chlorostoma funebralis. Molecular Ecology 24, 610-627.

GREen, J.M. (2014). Current state of herbicides in herbicide-resistant crops. Pest Management Science 70, 1351-1357.

Gu, J., Weber, K., Klemp, E., Winters, G., Franssen, S.U., WienPahl, I., Huylmans, 

A.K., ZeCher, K., Reusch, T.B.H., Bornberg-BAUER, E. \& Weber, A.P.M. (2012). Identifying core features of adaptive metabolic mechanisms for chronic heat stress attenuation contributing to systems robustness. Integrative Biology 4, 480-493.

Guannel, G., Arkema, K., Ruggiero, P. \& Verutes, G. (2016). The power of three: coral reefs, seagrasses and mangroves protect coastal regions and increase their resilience. PLoS One 11, e0158094.

Guerrero-Meseguer, L., MARÍN, A. \& SANZ-LÁZAro, C. (2017). Future heat waves due to climate change threaten the survival of $P$. oceanica seedlings. Environmental Pollution 230, $40-45$.

Guerrero-Meseguer, L., Marín, A. \& SAnZ-LÁZAro, C. (2020). Heat wave intensity can vary the cumulative effects of multiple environmental stressors on Posidonia oceanica seedlings. Marine Environmental Research 159, 105001.

Gunderson, A.R., ARMSTRong, E.J. \& Stillman, J.H. (2016). Multiple stressors in a changing world: the need for an improved perspective on physiological responses to the dynamic marine environment. Annual Review of Marine Science 8, 357-378.

Guy, C., Kaplan, F., Kopka, J., Selbig, J. \& Hincha, D.K. (2007). Metabolomics of temperature stress. Physiologia Plantarum 132, 220-235.

HAMmer, K.J., Borum, J., HASler-SheEtal, H., ShiEldS, E.C., SAND-Jensen, K. \& MoORE, K.A. (2018). High temperatures cause reduced growth, plant death and metabolic changes in eelgrass Zostera marina. Marine Ecology Progress Series 604, $121-132$.

Harley, C.D.G., Anderson, K.M., Demes, K.W., Jorve, J.P., Kordas, R.L., CoYle, T.A. \& GRAHAM, M.H. (2012). Effects of climate change on global seaweed communities. Journal of Phycology 48, 1064-1078.

HASANuZZAman, M., NAHAR, K. \& FuJitA, M. (2013). Extreme temperature responses, 
oxidative stress and antioxidant defense in plants. In Abiotic stress-Plant responses and applications in agriculture, pp.169-205. IntechOpen.

HENDRIKS, I.E., OlSEN, Y.S. \& DUARTE, C.M. (2017). Light availability and temperature, not increased $\mathrm{CO}_{2}$, will structure future meadows of Posidonia oceanica. Aquatic Botany 139, 32-36.

Hernán, G., Ortega, M.J., Gándara, A.M., Castejón, I., Terrados, J. \& Tomas, F. (2017). Future warmer seas: increased stress and susceptibility to grazing in seedlings of a marine habitat-forming species. Global Change Biology 23, 4530-4543.

Hillebrand, H., Borer, E.T., Bracken, M.E.S., Cardinale, B.J., Cebrian, J., Cleland, E.E., ElSer, J.J., Gruner, D.S., Stanley Harpole, W. \& NGai, J.T. (2009). Herbivore metabolism and stoichiometry each constrain herbivory at different organizational scales across ecosystems. Ecology Letters 12, 516-527.

Hobday, A.J., Alexander, L. V, Perkins, S.E., Smale, D.A., Straub, S.C., Oliver, E.C.J., Benthuysen, J.A., Burrows, M.T., Donat, M.G. \& Feng, M. (2016). A hierarchical approach to defining marine heatwaves. Progress in Oceanography 141, $227-238$

Hoegh-Guldberg, O., Mumby, P.J., Hooten, A.J., Steneck, R.S., Greenfield, P., Gomez, E., Harvell, C.D., Sale, P.F., Edwards, A.J., Caldeira, K., Knowlton, N., EAKIN, C.M., Iglesias-Prieto, R., MuthigA, N., Bradbury, R.H., ET AL. (2007). Coral reefs under rapid climate change and ocean acidification. Science 318, 1737-1742.

HogARTH, P.J. (2015). The biology of mangroves and seagrasses. Oxford University Press.

Holmer, M. \& HASLER-SHEETAL, H. (2014). Sulfide intrusion in seagrasses assessed by stable sulfur isotopes - a synthesis of current results. Frontiers in Marine Science 1, 64.

Holmer, M., Wirachwong, P. \& Thomsen, M.S. (2011). Negative effects of stress-resistant drift algae and high temperature on a small ephemeral seagrass species. Marine Biology 
158, 297-309.

1147

1148

1149

1150

1151

1152

1153

1154

1155

1156

1157

1158

1159

1160

1161

1162

1163

1164

1165

1166

1167

1168

1169

1170

Houston, K., Tucker, M.R., Chowdhury, J., Shirley, N. \& LitTle, A. (2016). The plant cell wall: A complex and dynamic structure as revealed by the responses of genes under stress conditions. Frontiers in Plant Science 7, 984.

HughES, A.R. \& STACHOWICZ, J.J. (2004). Genetic diversity enhances the resistance of a seagrass ecosystem to disturbance. Proceedings of the National Academy of Sciences of the United States of America 101, 8998-9002.

Hyndes, G.A., Heck, K.L., Vergés, A., Harvey, E.S., Kendrick, G.A., LAVERy, P.S., McMahon, K., Orth, R.J., Pearce, A., Vanderklift, M., Wernberg, T., Whiting, S. \& WILSON, S. (2016). Accelerating tropicalization and the transformation of temperate seagrass meadows. BioScience 66, 938-945.

InVERS, O., PEREZ, M. \& Romero, J. (1999). Bicarbonate utilization in seagrass photosynthesis: role of carbonic anhydrase in Posidonia oceanica (L.) Delile and Cymodocea nodosa (Ucria) Ascherson. Journal of Experimental Marine Biology and Ecology 235, 125-133.

JahnKe, M., D’Esposito, D., OrRÙ, L., LAmontanara, A., DAtTolo, E., BADAlamenti, F., MazzuCA, S., Procaccini, G. \& Orsini, L. (2019). Adaptive responses along a depth and a latitudinal gradient in the endemic seagrass Posidonia oceanica. Heredity 122, 233-243.

Janni, M., Gullì, M., Maestri, E., Marmiroli, M., VAlliyodan, B., NGuYen, H.T. \& MARMIROLI, N. (2020). Molecular and genetic bases of heat stress responses in crop plants and breeding for increased resilience and productivity. Journal of Experimental Botany 71, 3780-3802.

JARVIS, J.C., BRUSH, M.J. \& MoORE, K.A. (2014). Modeling loss and recovery of Zostera marina beds in the Chesapeake Bay: The role of seedlings and seed-bank viability. 

Aquatic Botany 113, 32-45.

1172

1173

1174

1175

1176

1177

1178

1179

1180

1181

1182

1183

1184

1185

1186

1187

1188

1189

1190

1191

1192

1193

1194

1195

JAYATHILAKE, D.R.M. \& Costello, M.J. (2018). A modelled global distribution of the seagrass biome. Biological Conservation 226, 120-126.

JordÀ, G., MARBÀ, N. \& DUARTE, C.M. (2012). Mediterranean seagrass vulnerable to regional climate warming. Nature Climate Change 2, 821-824.

Jueterbock, A., Boström, C., Coyer, J.A., Olsen, J.L., KopP, M., Dhanasiri, A.K.S., Smolina, I., Arnaud-Haond, S., VAn De Peer, Y. \& HoArau, G. (2020). The seagrass methylome is associated with variation in photosynthetic performance among clonal shoots. Frontiers in Plant Science 11, 1387.

Jueterbock, A., Franssen, S.U., Bergmann, N., Gu, J., Coyer, J.A., Reusch, T.B.H., BornberG-BAuer, E. \& Olsen, J.L. (2016). Phylogeographic differentiation versus transcriptomic adaptation to warm temperatures in Zostera marina, a globally important seagrass. Molecular Ecology 25, 5396-5411.

KALDY, J.E. \& SHAFER, D.J. (2013). Effects of salinity on survival of the exotic seagrass Zostera japonica subjected to extreme high temperature stress. Botanica Marina 56, 7582.

KALDY, J.E., ShafER, D.J. \& MAGOUN, A.D. (2015). Duration of temperature exposure controls growth of Zostera japonica: implications for zonation and colonization. Journal of Experimental Marine Biology and Ecology 464, 68-74.

KELLER, C.F. (2009). Global warming: A review of this mostly settled issue. Stochastic Environmental Research and Risk Assessment 23, 643-676.

Kendrick, G.A., Nowicki, R., Olsen, Y.S., Strydom, S., Fraser, M.W., Sinclair, E.A., Statton, J., Hovey, R.K., Thomson, J.A., Burkholder, D., McMahon, K.M., Kilminster, K., Hetzel, Y., Fourqurean, J.W., Heithaus, M.R., et AL. (2019). A systematic review of how multiple stressors from an extreme event drove ecosystem- 
wide loss of resilience in an iconic seagrass community. Frontiers in Marine Science $\mathbf{6}$, 455.

KERR, E.A. \& STROTHER, S. (1985). Effects of irradiance, temperature and salinity on photosynthesis of Zostera muelleri. Aquatic Botany 23, 177-183.

KIANG, J.G. \& TsOKOS, G.C. (1998). Heat shock protein 70 kDa: molecular biology, biochemistry, and physiology. Pharmacology \& Therapeutics 80, 183-201.

KIM, M., QIN, L.Z., KIM, S.H., Song, H.J., KIM, Y.K. \& LEE, K.S. (2019). Influence of water temperature anomalies on the growth of Zostera marina plants held under high and low irradiance levels. Estuaries and Coasts 43, 463-476.

KINOSHITA, T. \& SEKI, M. (2014). Epigenetic memory for stress response and adaptation in plants. Plant and Cell Physiology 55, 1859-1863.

Koch, M., Bowes, G., Ross, C. \& ZHANG, X.H. (2013). Climate change and ocean acidification effects on seagrasses and marine macroalgae. Global Change Biology 19, $103-132$.

Koch, M.S., SchopmeYeR, S., KyHN-HANSEn, C. \& MAdDEN, C.J. (2007). Synergistic effects of high temperature and sulfide on tropical seagrass. Journal of Experimental Marine Biology and Ecology 341, 91-101.

Kong, F., Li, H., Sun, P., ZhOU, Y. \& MAO, Y. (2014). De Novo Assembly and Characterization of the Transcriptome of Seagrass Zostera marina Using Illumina Paired-End Sequencing. PLoS One 9, e112245.

Koutalianou, M., ORfANIDIS, S. \& KATSAROS, C. (2016). Effects of high temperature on the ultrastructure and microtubule organization of interphase and dividing cells of the seagrass Cymodocea nodosa. Protoplasma 253, 299-310.

Kuo, J. \& Den Hartog, C. (2000). Seagrasses: A profile of an ecological group. Biologia Marina Mediterranea 7, 3-17. 
Kurdyukov, S. \& Bullock, M. (2016). DNA Methylation Analysis: Choosing the Right Method. Biology 5, 3.

LAMb, J.B., VAN DE WATER, J.A.J.M.J.M., Bourne, D.G., Altier, C., Hein, M.Y., Fiorenza, E.A., Abu, N., Jompa, J. \& Harvell, C.D. (2017). Seagrass ecosystems reduce exposure to bacterial pathogens of humans, fishes, and invertebrates. Science 355, 731-733.

LATTEMANN, S. \& HÖPNER, T. (2008). Environmental impact and impact assessment of seawater desalination. Desalination 220, 1-15.

Lee, H., Golicz, A.A., BAyer, P.E., Jiao, Y., TAng, H., PAterson, A.H., SABlok, G., Krishnaraj, R.R., Chan, C.-K.K., BAtley, J., KendRICK, G.A., LARKUM, A.W.D., RALPH, P.J. \& EDWARDS, D. (2016). The genome of a Southern Hemisphere seagrass species (Zostera muelleri). Plant Physiology 172, 272-283.

LEE, K.-S., PARK, S.R. \& KIM, Y.K. (2007a). Effects of irradiance, temperature, and nutrients on growth dynamics of seagrasses: a review. Journal of Experimental Marine Biology and Ecology 350, 144-175.

LEE, K.-S., PARK, J.-I., KIM, Y.K., PARK, S.R. \& KIM, J.-H. (2007b). Recolonization of Zostera marina following destruction caused by a red tide algal bloom: the role of new shoot recruitment from seed banks. Marine Ecology Progress Series 342, 105-115.

Lenton, T.M., Rockström, J., GAFFney, O., Rahmstorf, S., Richardson, K., StefFen, W. \& SCHELlnHUBER, H.J. (2019). Climate tipping points - too risky to bet against. Nature 575, 592-595.

Les, D.H., Cleland, M.A. \& WAycotT, M. (1997). Phylogenetic studies in Alismatidae, II: Evolution of marine angiosperms (seagrasses) and hydrophily. Systematic Botany 22, $443-463$.

Lewis, S.E., Brodie, J.E., BAinBridge, Z.T., Rohde, K.W., DAvis, A.M., MAsters, B.L., 
Maughan, M., Devlin, M.J., Mueller, J.F. \& SchaffelKe, B. (2009). Herbicides: a new threat to the Great Barrier Reef. Environmental Pollution 157, 2470-2484.

LiaO, E., Lu, W., YAn, X.H., JiAnG, Y. \& KidwEll, A. (2015). The coastal ocean response to the global warming acceleration and hiatus. Scientific Reports 5, 1-10.

LIPKIN, Y. (1975). Halophila stipulacea, a review of a successful immigration. Aquatic Botany 1, 203-215.

1252

1253

1254

1255

1256

1257

1258

1259

1260

1261

1262

1263

1264

1265

1266

1267

1268

1269

1270

LIU, J., FenG, L., LI, J. \& HE, Z. (2015). Genetic and epigenetic control of plant heat responses. Frontiers in Plant Science 06, 267.

LiU, J., TANG, X., WANG, Y., ZANG, Y. \& ZhOU, B. (2016). A Zostera marina manganese superoxide dismutase gene involved in the responses to temperature stress. Gene $\mathbf{5 7 5}$, $718-724$.

MACREADIE, P.I. \& HARDY, S.S.S. (2018). Response of seagrass 'Blue Carbon' stocks to increased water temperatures. Diversity 10, 115.

Malandrakis, E., Dadali, O., Kavouras, M., Danis, T., Panagiotaki, P., Miliou, H., Tsioli, S., Orfanidis, S., KÜPPER, F.C. \& EXADACTYLOS, A. (2017). Identification of the abiotic stress-related transcription in little Neptune grass Cymodocea nodosa with RNA-seq. Marine Genomics 34, 47-56.

Marbà, N., Calleja, M.L., Duarte, C.M., Álvarez, E., Díaz-Almela, E. \& Holmer, M. (2007). Iron additions reduce sulfide intrusion and reverse seagrass (Posidonia oceanica) decline in carbonate sediments. Ecosystems 10, 745-756.

MARBÀ, N., DíAZ-Almela, E. \& DuARTE, C.M. (2014). Mediterranean seagrass (Posidonia oceanica) loss between 1842 and 2009. Biological Conservation 176, 183-190.

MARBÀ, N. \& DuARTE, C.M. (2010). Mediterranean warming triggers seagrass (Posidonia oceanica) shoot mortality. Global Change Biology 16, 2366-2375.

Marín-GuiraO, L., Bernardeau-Esteller, J., García-Muñoz, R., RAmOS, A., OnTORIA, 

Y., Romero, J., PÉrez, M., RuIZ, J.M. \& Procaccini, G. (2018). Carbon economy of Mediterranean seagrasses in response to thermal stress. Marine Pollution Bulletin 135, $617-629$.

Marín-Guirao, L., Entrambasaguas, L., Dattolo, E., Ruiz, J.M. \& Procaccini, G. (2017). Molecular mechanisms behind the physiological resistance to intense transient warming in an iconic marine plant. Frontiers in Plant Science 8, 1142.

Marín-Guirao, L., Ruiz, J.M., Dattolo, E., Garcia-Munoz, R. \& Procaccini, G. (2016). Physiological and molecular evidence of differential short-term heat tolerance in Mediterranean seagrasses. Scientific Reports 6, 28615.

MARÍN-GuiRAO, L., SANDOVAL-GiL, J.M., RuíZ, J.M. \& SÁNCHEZ-LIZASO, J.L. (2011). Photosynthesis, growth and survival of the Mediterranean seagrass Posidonia oceanica in response to simulated salinity increases in a laboratory mesocosm system. Estuarine, Coastal and Shelf Science 92, 286-296.

Marín-GuiraO, L., EnTrambasaguas, L., Ruiz, J.M. \& PROCACCINI, G. (2019). Heat-stress induced flowering can be a potential adaptive response to ocean warming for the iconic seagrass Posidonia oceanica. Molecular Ecology 28, 2486-2501.

MARSh JR, J.A., DENNISON, W.C. \& AlBERTE, R.S. (1986). Effects of temperature on photosynthesis and respiration in eelgrass (Zostera marina L.). Journal of Experimental Marine Biology and Ecology 101, 257-267.

MASINI, R.J., CARY, J.L., SimPSON, C.J. \& MCCOMB, A.J. (1995). Effects of light and temperature on the photosynthesis of temperate meadow-forming seagrasses in Western Australia. Aquatic Botany 49, 239-254.

MASINI, R.J. \& MANNING, C.R. (1997). The photosynthetic responses to irradiance and temperature of four meadow-forming seagrasses. Aquatic Botany 58, 21-36.

Massa, S.I., Arnaud-Haond, S., PeArson, G.A. \& Serrão, E.A. (2009). Temperature 
tolerance and survival of intertidal populations of the seagrass Zostera noltii (Hornemann) in Southern Europe (Ria Formosa, Portugal). Hydrobiologia 619, 195201.

Massa, S.I., Pearson, G.A., Aires, T., Kube, M., Olsen, J.L., Reinhardt, R., Serrão, E.A. \& ARNAUD-HAOND, S. (2011). Expressed sequence tags from heat-shocked seagrass Zostera noltii (Hornemann) from its southern distribution range. Marine Genomics 4, 181-188.

Masson-Delmotte, V., Zhai, P., Pörtner, H.-O., Roberts, D., Skea, J., Shukla, P.R., Pirani, A., Moufouma-OKiA, W., PÉAn, C. \& PidCock, R. (2018). Global Warming of $1.5^{\circ} \mathrm{C}$ : An IPCC Special Report on the Impacts of Global Warming of $1.5^{\circ} \mathrm{C}$ Above Preindustrial Levels and Related Global Greenhouse Gas Emission Pathways, in the Context of Strengthening the Global Response to the Threat of Climate Change. World Meteorological Organization Geneva, Switzerland.

MAYOT, N., BoudouRESQUE, C.F. \& LERICHE, A. (2005). Unexpected response of the seagrass Posidonia oceanica to a warm-water episode in the North Western Mediterranean Sea. Comptes Rendus Biologies 328, 291-296.

MCGLATHERY, K.J. (2001). Macroalgal blooms contribute to the decline of seagrass in nutrient-enriched coastal waters. Journal of Phycology 37, 453-456.

McKenZie, L., Nordlund, L.M., Jones, B.L., Cullen-Unsworth, L.C., Roelfsema, C.M. \& UNSWORTH, R. (2020). The global distribution of seagrass meadows. Environmental Research Letters 15, 074041.

MCKENZIE, L.J., FINKBEINER, M.A. \& KIRKMAN, H. (2001). Methods for mapping seagrass distribution. In Global seagrass research methods, pp. 101-121. Elsevier.

MeEHL, G.A. \& TEBALDI, C. (2004). More intense, more frequent, and longer lasting heat waves in the 21 st century. Science $\mathbf{3 0 5}$, 994-997. 
MolinIER, J., RIES, G., ZIPFEL, C. \& HoHN, B. (2006). Transgeneration memory of stress in plants. Nature 442, 1046-1049.

MONASTERSKY, R. (2013). Global carbon dioxide levels near worrisome milestone. Nature 497, 13-14.

Mota, C.F., Engelen, A.H., Serrao, E.A., Coelho, M.A.G., MarbÀ, N. \& Krause-Jensen, D. (2018). Differentiation in fitness-related traits in response to elevated temperatures between leading and trailing edge populations of marine macrophytes. PLoS One 13, e0203666.

MvUNGI, E.F. \& PILlAY, D. (2019). Eutrophication overrides warming as a stressor for a temperate African seagrass (Zostera capensis). PLoS One 14, e0215129.

Negri, A.P., Flores, F., Mercurio, P., Mueller, J.F. \& Collier, C.J. (2015). Lethal and sub-lethal chronic effects of the herbicide diuron on seagrass. Aquatic Toxicology 165, 73-83.

NEJRUP, L.B. \& PEDERSEN, M.F. (2008). Effects of salinity and water temperature on the ecological performance of Zostera marina. Aquatic Botany 88, 239-246.

NGUYen, H.M., YADAV, N.S., BARAK, S., LiMA, F.P., SAPIR, Y. \& WiNTERS, G. (2020a). Responses of invasive and native populations of the seagrass Halophila stipulacea to simulated climate change. Frontiers in Marine Science 6, 812.

Nguyen, H.M., Kim, M., RalPh, P.J., Marín-Guirao, L., Pernice, M. \& Procaccini, G. (2020b). Stress memory in seagrasses: first insight into the effects of thermal priming and the role of epigenetic modifications. Frontiers in Plant Science 11, 494.

Nicholls, R.J. \& CAZENAVE, A. (2010). Sea-level rise and its impact on coastal zones. Science 328, 1517-1520.

Nishizawa, A., Yabuta, Y. \& ShigeOKA, S. (2008). Galactinol and raffinose constitute a novel function to protect plants from oxidative damage. Plant Physiology 147, 1251- 
1347

Nowicki, R.J., Thomson, J.A., Burkholder, D.A., Fourqurean, J.W. \& Heithaus, M.R. (2017). Predicting seagrass recovery times and their implications following an extreme climate event. Marine Ecology Progress Series 567, 79-93.

O’Brien, K.R., WAycott, M., MAXwell, P., Kendrick, G.A., Udy, J.W., Ferguson, A.J.P., Kilminster, K., ScAnes, P., McKenzie, L.J., McMahon, K., AdAMs, M.P., SAMPeRVillarreal, J., Collier, C., LyOnS, M., Mumby, P.J., ET AL. (2018). Seagrass ecosystem trajectory depends on the relative timescales of resistance, recovery and disturbance. Marine Pollution Bulletin 134, 166-176.

Olesen, B., Marba, N., Duarte, C.M., SAVela, R.S. \& Fortes, M.D. (2004). Recolonization dynamics in a mixed seagrass meadow: the role of clonal versus sexual processes. Estuaries 27, 770-780.

Oliver, E.C.J., Burrows, M.T., Donat, M.G., Sen Gupta, A., AlexAnder, L. V., Perkins-KirkPATrick, S.E., Benthuysen, J.A., Hobday, A.J., HolbroOK, N.J., Moore, P.J., Thomsen, M.S., Wernberg, T. \& Smale, D.A. (2019). Projected Marine Heatwaves in the 21st Century and the Potential for Ecological Impact. Frontiers in Marine Science 6, 734.

Oliver, E.C.J., Donat, M.G., Burrows, M.T., Moore, P.J., Smale, D.A., Alexander, L. V., Benthuysen, J.A., Feng, M., Sen Gupta, A., Hobday, A.J., Holbrook, N.J., Perkins-KirkPATRick, S.E., Scannell, H.A., StRAUb, S.C. \& WernBerg, T. (2018). Longer and more frequent marine heatwaves over the past century. Nature Communications 9, 1-12.

Olsen, J.L., Rouzé, P., Verhelst, B., Lin, Y.C., BAyer, T., Collen, J., DAtTolo, E., De Paoli, E., Dittami, S., Maumus, F., Michel, G., Kersting, A., Lauritano, C., LOHAUS, R., TÖPEL, M., ET AL. (2016). The genome of the seagrass Zostera marina 
reveals angiosperm adaptation to the sea. Nature 530, 331-335.

1372

1373

OlSEN, Y.S. \& DUARTE, C.M. (2015). Combined effect of warming and infection by Labyrinthula sp. on the Mediterranean seagrass Cymodocea nodosa. Marine Ecology Progress Series 532, 101-109.

Olsen, Y.S., Potouroglou, M., Garcias-Bonet, N. \& Duarte, C.M. (2014). Warming reduces pathogen pressure on a climate-vulnerable seagrass species. Estuaries and Coasts 38, 659-667.

Olsen, Y.S., SÁnChEZ-CAMAChO, M., MARBÀ, N. \& DuARTE, C.M. (2012). Mediterranean seagrass growth and demography responses to experimental warming. Estuaries and Coasts 35, 1205-1213.

Ontoria, Y., Cuesta-Gracia, A., Ruiz, J.M., Romero, J. \& PÉrez, M. (2019a). The negative effects of short-term extreme thermal events on the seagrass Posidonia oceanica are exacerbated by ammonium additions. PLoS One 14, e 0222798.

Ontoria, Y., GonZalez-Guedes, E., SAnMartí, N., Bernardeau-Esteller, J., Ruiz, J.M., ROMERO, J. \& PÉREZ, M. (2019b). Interactive effects of global warming and eutrophication on a fast-growing Mediterranean seagrass. Marine Environmental Research 145, 27-38.

ORTBAUER, M. \& POPP, M. (2008). Functional role of polyhydroxy compounds on protein structure and thermal stability studied by circular dichroism spectroscopy. Plant Physiology and Biochemistry 46, 428-434.

Orth, R.J., Carruthers, T.J.B., Dennison, W.C., Duarte, C.M., Fourqurean, J.W., Heck, K.L., Hughes, A.R., Kendrick, G.A., Kenworthy, W.J. \& Olyarnik, S. (2006). A global crisis for seagrass ecosystems. AIBS Bulletin 56, 987-996.

Orth, R.J., Harwell, M.C., Bailey, E.M., Bartholomew, A., Jawad, J.T., Lombana, A. V, MoOre, K.A., RhodE, J.M. \& WoOdS, H.E. (2000). A review of issues in seagrass 
seed dormancy and germination: implications for conservation and restoration. Marine Ecology Progress Series 200, 277-288.

OSCAR, M.A., BARAK, S. \& WinTERS, G. (2018). The tropical invasive seagrass, Halophila stipulacea has a superior ability to tolerate dynamic changes in salinity levels compared to its freshwater relative, Vallisneria americana. Frontiers in Plant Science 9, 950.

Pagès, J.F., Smith, T.M., Tomas, F., SAnMartí, N., BoAda, J., De Bari, H., PÉrez, M., Romero, J., Arthur, R. \& Alcoverro, T. (2018). Contrasting effects of ocean warming on different components of plant-herbivore interactions. Marine Pollution Bulletin 134, 55-65.

PARK, C.-J. \& SEO, Y.-S. (2015). Heat shock proteins: a review of the molecular chaperones for plant immunity. The Plant Pathology Journal 31, 323-333.

PaZzaglia, J., Reusch, T.B.H., Terlizzi, A., Marín-GuiRaO, L. \& Procaccini, G. (2021). Prompt phenotypic plasticity under rapid global changes: the intrinsic force for future seagrasses survival. Evolutionary Applications 00, 1-21.

Pazzaglia, J., Santillán-S armiento, A., Helber, S.B., Ruocco, M., Terlizzi, A., MARÍN-GuiRAO, L. \& PROCACCINI, G. (2020). Does warming enhance the effects of eutrophication in the seagrass Posidonia oceanica? Frontiers in Marine Science 7, 1067.

Pedersen, O., Colmer, T.D., Borum, J., Zavala-Perez, A. \& Kendrick, G.A. (2016). Heat stress of two tropical seagrass species during low tides-impact on underwater net photosynthesis, dark respiration and diel in situ internal aeration. New Phytologist 210, $1207-1218$

Pereda-Briones, L., Terrados, J. \& Tomas, F. (2019). Negative effects of warming on seagrass seedlings are not exacerbated by invasive algae. Marine Pollution Bulletin 141, $36-45$.

PereZ, M. \& Romero, J. (1992). Photosynthetic response to light and temperature of the 

seagrass Cymodocea nodosa and the prediction of its seasonality. Aquatic Botany 43, $51-62$.

Pernice, M., Schliep, M., Szabo, M., Rasheed, M., Bryant, C., York, P., Chartrand, K., Petrou, K. \& RalPh, P. (2015). Development of a molecular biology tool kit to monitor dredging-related light stress in the seagrass Zostera muelleri ssp. capricorni in Port Curtis. A Report for Gladstone Ports Corporation Limited. Report No. 15/08. TropWATER, Cairns, QLD, Australia.

Phinn, S., Roelfsema, C., Kovacs, E., Canto, R., Lyons, M., SAunders, M. \& Maxwell, P. (2018). Mapping, monitoring and modelling seagrass using remote sensing techniques. In Seagrasses of Australia, pp. 445-487. Springer.

Plus, M., Deslous-Paoli, J.-M. \& Dagault, F. (2003). Seagrass (Zostera marina L.) bed recolonisation after anoxia-induced full mortality. Aquatic Botany 77, 121-134.

Prado, P., Tomas, F., Alcoverro, T. \& Romero, J. (2007). Extensive direct measurements of Posidonia oceanica defoliation confirm the importance of herbivory in temperate seagrass meadows. Marine Ecology Progress Series 340, 63-71.

Procaccini, G., Beer, S., BjöRK, M., Olsen, J., Mazzuca, S. \& SAntos, R. (2012).

Seagrass ecophysiology meets ecological genomics: are we ready? Marine Ecology 33, 522527.

Procaccini, G., Olsen, J.L. \& Reusch, T.B.H. (2007). Contribution of genetics and genomics to seagrass biology and conservation. Journal of Experimental Marine Biology and Ecology 350, 234-259.

Procaccini, G., Ruocco, M., Marín-Guirao, L., Dattolo, E., Brunet, C., D’EsPosito, D., Lauritano, C., Mazzuca, S., Serra, I.A., Bernardo, L., Piro, A., Beer, S., BJÖRK, M., GULlSTRÖM, M., BuAPET, P., ET AL. (2017). Depth-specific fluctuations of gene expression and protein abundance modulate the photophysiology in the seagrass 
Purnama, P.R., Hariyanto, S., Sri, Y., Manuhara, W. \& Purnobasuki, H. (2019). Gene expression of antioxidant enzymes and heat shock proteins in tropical seagrass Thalassia hemprichii under heat Stress. Taiwania 64, 117-123.

QU, A.L., Ding, Y.F., JIANG, Q. \& ZHU, C. (2013). Molecular mechanisms of the plant heat stress response. Biochemical and Biophysical Research Communications 432, 203-207.

RABALAIS, N.N., HARPER, D.E. \& TURNER, R.E. (2001). Responses of nekton and demersal and benthic fauna to decreasing oxygen concentrations. In Coastal Hypoxia: Consequences for Living Resources and Ecosystems, pp. 115-128. American Geophysical Union.

RABALAIS, N.N., TuRnER, R.E., DiAZ, R.J. \& Justić, D. (2009). Global change and eutrophication of coastal waters. Journal of Marine Science 66, 1528-1537.

RALPH, P.J. (1998). Photosynthetic response of laboratory-cultured Halophila ovalis to thermal stress. Marine Ecology Progress Series 171, 123-130.

RALPH, P.J. (1999). Photosynthetic response of Halophila ovalis (R. Br.) Hook. f. to combined environmental stress. Aquatic Botany 65, 83-96.

RalPh, P.J., Tomasko, D., MoORe, K., Seddon, S. \& Macinnis-NG, C.M.O. (2007). Human impacts on seagrasses: eutrophication, sedimentation, and contamination. In Seagrasses:

RANSBOTYL, V.\& REUSCH, T.B. (2006). Housekeeping gene selection for quantitative realBiology, Ecology and Conservation, pp. 567-593. Springer.

Ramesh, R., Banerjee, K., Paneerselvam, A., Raghuraman, R., Purvaja, R. \& LAKSHMI, A. (2019). Importance of seagrass management for effective mitigation of time PCR assays in the seagrass Zostera marina subjected to heat stress. Limnology and Oceanography: Methods 4, 367-373. 
RASHEED, M.A. \& UNSWORTH, R.K.F.F. (2011). Long-term climate-associated dynamics of a tropical seagrass meadow: implications for the future. Marine Ecology Progress Series 422, 93-103.

RAVEN, J.A. \& SCRIMGEOUR, C.M. (1997). The influence of anoxia on plants of saline habitats with special reference to the sulphur cycle. Annals of Botany 79, 79-86.

RENN, C.E. (1936). The wasting disease of Zostera marina: I. A phytological investigation of the diseased plant. The Biological Bulletin 70, 148-158.

Repolho, T., Duarte, B., Dionísio, G., Paula, J.R., Lopes, A.R., Rosa, I.C., Grilo, T.F., CAÇADOR, I., CALADO, R. \& RosA, R. (2017). Seagrass ecophysiological performance under ocean warming and acidification. Scientific Reports 7, 41443.

REUSCH, T.B.H., EHLERS, A., HÄMMERLI, A. \& WORM, B. (2005). Ecosystem recovery after climatic extremes enhanced by genotypic diversity. Proceedings of the National Academy of Sciences of the United States of America 102, 2826-2831.

Reusch, T.B.H., Veron, A.S., Preuss, C., Weiner, J., Wissler, L., Beck, A., Klages, S., KUBE, M., REINHARDT, R. \& BORnBERG-BAUER, E. (2008). Comparative analysis of expressed sequence tag (EST) libraries in the seagrass Zostera marina subjected to temperature stress. Marine Biotechnology 10, 297-309.

REuSCH, T.B.H. \& WoOD, T.E. (2007). Molecular ecology of global change. Molecular Ecology 16, 3973-3992.

Reynolds, L.K., DuBois, K., AвbotT, J.M., Williams, S.L. \& StaChowicz, J.J. (2016a). Response of a habitat-forming marine plant to a simulated warming event is delayed, genotype specific, and varies with phenology. PloS One 11, e0154532.

REYNOLDS, L.K., WAYCotT, M., MCGlatheRy, K.J. \& ORTH, R.J. (2016b). Ecosystem services returned through seagrass restoration. Restoration Ecology 24, 583-588.

RICHARDSON, P.J., LEFCHECK, J.S. \& ORTH, R.J. (2018). Warming temperatures alter the 
relative abundance and distribution of two co-occurring foundational seagrasses in chesapeake bay, USA. Marine Ecology Progress Series 599, 65-74.

Robblee, M., Barber, T., Carlson, P., Durako, M., Fourqurean, J., Muehlstein, L., Porter, D., YARbro, L., ZiEMAN, R. \& ZiEMAN, J. (1991). Mass mortality of the tropical seagrass Thalassia testudinum in Florida Bay (USA). Marine Ecology Progress Series 71, 297-299.

Ruiz, J.M., MARÍN-GuiRAo, L., GARCÍA-MuÑOZ, R., RAMOS-SEgurA, A., BERNARDEAUEsteller, J., PÉrez, M., Sanmartí, N., Ontoria, Y., Romero, J., Arthur, R., Alcoverro, T. \& ProcacCini, G. (2018). Experimental evidence of warming-induced flowering in the Mediterranean seagrass Posidonia oceanica. Marine Pollution Bulletin 134, 49-54.

Ruíz, J.M., MARÍN-GuIRAO, L. \& SANDOVAL-GIL, J.M. (2009). Responses of the Mediterranean seagrass Posidonia oceanica to in situ simulated salinity increase. Botanica Marina 52, 459-470.

Ruiz-Montoya, L., Lowe, R.J., VAn NIEL, K.P. \& Kendrick, G.A. (2012). The role of hydrodynamics on seed dispersal in seagrasses. Limnology and Oceanography 57, $1257-1265$.

Ruocco, M., De Luca, P., Marín-GuiRao, L. \& ProcacCini, G. (2019a). Differential Leaf Age-Dependent Thermal Plasticity in the Keystone Seagrass Posidonia oceanica. Frontiers in Plant Science 10, 1556.

RuOCCO, M., MARÍN-GuiRAo, L. \& ProcaCCINI, G. (2019b). Within- and among-leaf variations in photo-physiological functions, gene expression and DNA methylation patterns in the large-sized seagrass Posidonia oceanica. Marine Biology 166, 24.

Saha, M., Barboza, F.R., Somerfield, P.J., Al-Janabi, B., Beck, M., BraKel, J., Ito, M., Pansch, C., Nascimento-Schulze, J.C., Jakobsson Thor, S., Weinberger, F. \& 
SAWALL, Y. (2019). Response of foundation macrophytes to near-natural simulated marine heatwaves. Global Change Biology 26, 417-430.

SAlo, T. \& PedERSEN, M.F. (2014). Synergistic effects of altered salinity and temperature on estuarine eelgrass (Zostera marina) seedlings and clonal shoots. Journal of Experimental Marine Biology and Ecology 457, 143-150.

SALVUCCI, M.E. \& CRAFTS-BRANDNER, S.J. (2004). Mechanism for deactivation of Rubisco under moderate heat stress. Physiologia Plantarum 122, 513-519.

SANDIFER, P.A. \& SuTTON-GRIER, A.E. (2014). Connecting stressors, ocean ecosystem services, and human health. Natural Resources Forum 38, 157-167.

SAndoval-Gil, J.M., Ruiz, J.M., MaríN-GuiRaO, L., BernardeAu-Esteller, J. \& SÁNCHEZ-LIZASO, J.L. (2014). Ecophysiological plasticity of shallow and deep populations of the Mediterranean seagrasses Posidonia oceanica and Cymodocea nodosa in response to hypersaline stress. Marine Environmental Research 95, 39-61.

SAVVA, I., BenNETt, S., RoCA, G., JORDÀ, G \& MARBÀ, N. (2018). Thermal tolerance of Mediterranean marine macrophytes: Vulnerability to global warming. Ecology and Evolution 8, 12032-12043.

SCHÄR, C. \& JENDRITZKY, G. (2004). Hot news from summer 2003. Nature 432, 559-560.

Scheibling, R.E., PAtriquin, D.G. \& Filbee-Dexter, K. (2018). Distribution and abundance of the invasive seagrass Halophila stipulacea and associated benthic macrofauna in Carriacou, Grenadines, Eastern Caribbean. Aquatic Botany 144, 1-8.

SchlieP, M., Pernice, M., Sinutok, S., Bryant, C. V, York, P.H., Rasheed, M.A. \& RALPH, P.J. (2015). Evaluation of reference genes for RT-qPCR studies in the seagrass Zostera muelleri exposed to light limitation. Scientific Reports 5, 17051.

SEDDON, S. \& CHESHIRE, A.C. (2001). Photosynthetic response of Amphibolis antarctica and Posidonia australis to temperature and desiccation using chlorophyll fluorescence. 
Marine Ecology Progress Series 220, 119-130.

1547

1548

1549

1550

1551

1552

1553

1554

1555

1556

1557

1558

1559

1560

1561

1562

1563

1564

1565

1566

1567

1568

1569

1570

SEdDOn, S., Connolly, R.M. \& Edyvane, K.S. (2000). Large-scale seagrass dieback in northern Spencer Gulf, South Australia. Aquatic Botany 66, 297-310.

Shakun, J.D., Clark, P.U., He, F., Marcott, S.A., MiX, A.C., LiU, Z., Otto-Bliesner, B., SCHMITTNER, A. \& BARD, E. (2012). Global warming preceded by increasing carbon dioxide concentrations during the last deglaciation. Nature 484, 49-54.

SHARKEY, T.D. (2005). Effects of moderate heat stress on photosynthesis: importance of thylakoid reactions, rubisco deactivation, reactive oxygen species, and thermotolerance provided by isoprene. Plant, Cell \& Environment 28, 269-277.

ShIELDS, E.C., PARRISH, D. \& MOORE, K. (2019). Short-Term Temperature Stress Results in Seagrass Community Shift in a Temperate Estuary. Estuaries and Coasts 42, 755-764.

Short, F.T., CARruthers, T., Dennison, W. \& WAyCott, M. (2007). Global seagrass distribution and diversity: a bioregional model. Journal of Experimental Marine Biology and Ecology 350, 3-20.

SMALE, D.A. (2020). Impacts of ocean warming on kelp forest ecosystems. New Phytologist 225, 1447-1454.

Smale, D.A., Wernberg, T., Oliver, E.C.J., Thomsen, M., Harvey, B.P., Straub, S.C., Burrows, M.T., Alexander, L. V, Benthuysen, J.A. \& Donat, M.G. (2019). Marine heatwaves threaten global biodiversity and the provision of ecosystem services. Nature Climate Change 9, 306-312.

Smith, R., Middlebrook, R., Turner, R., Huggins, R., VArdy, S. \& Warne, M. (2012) Large-scale pesticide monitoring across Great Barrier Reef catchments-paddock to reef integrated monitoring, modelling and reporting program. Marine Pollution Bulletin 65, 117-127.

SoIsSOnS, L.M., HAANSTRA, E.P., VAn KATwiJK, M.M., Asmus, R., Auby, I., BARILlÉ, L., 
Brun, F.G., CARdoso, P.G., Desroy, N., Fournier, J., GANTHY, F., GARMENDiA, J.-M., GodeT, L., GRILO, T.F., KADEL, P., ET AL. (2018). Latitudinal patterns in european seagrass carbon reserves: influence of seasonal fluctuations versus short-term stress and disturbance events. Frontiers in Plant Science 9, 88.

Solomon, S., Plattner, G.-K., Knutti, R. \& Friedlingstein, P. (2009). Irreversible climate change due to carbon dioxide emissions. Proceedings of the National Academy of Sciences 106, 1704-1709.

SøREnSEn, J.G., KRISTEnSEN, T.N. \& LOESCHCKE, V. (2003). The evolutionary and ecological role of heat shock proteins. Ecology Letters 6, 1025-1037.

StEINER, S.C.C. \& WiLleTte, D.A. (2015). The Expansion of Halophila Stipulacea (Hydrocharitaceae, Angiospermae) is Changing the Seagrass Landscape in the Commonwealth of Dominica Lesser Antiles. Caribbean Naturalist 22, 1-19.

STONE, S.L. (2014). The role of ubiquitin and the $26 \mathrm{~S}$ proteasome in plant abiotic stress signaling. Frontiers in Plant Science 5, 135.

Strydom, S., Murray, K., Wilson, S., Huntley, B., Rule, M., Heithaus, M., Bessey, C., Kendrick, G.A., BurKholder, D., Holmes, T., Fraser, M.W. \& ZduniC, K. (2020). Too hot to handle: unprecedented seagrass death driven by marine heatwave in a World Heritage Area. Global Change Biology 26, 3525-3538.

Sullivan, B.K., Trevathan-Tackett, S.M., Neuhauser, S. \& Govers, L.L. (2018). Hostpathogen dynamics of seagrass diseases under future global change. Marine Pollution Bulletin 134, 75-88.

Tan, Y.M., Dalby, O., Kendrick, G.A., Statton, J., Sinclair, E.A., Fraser, M.W., Macreadie, P.I., Gillies, C.L., Coleman, R.A. \& WAycotT, M. (2020). Seagrass restoration is possible: Insights and lessons from Australia and New Zealand. Frontiers in Marine Science 7, 617. 
TArquinio, F., Hyndes, G.A., LAverock, B., Koenders, A. \& SÄwström, C. (2019). The seagrass holobiont: Understanding seagrass-bacteria interactions and their role in seagrass ecosystem functioning. FEMS Microbiology Letters 366, fnz057.

Telesca, L., Belluscio, A., Criscoli, A., Ardizzone, G., Apostolaki, E.T., Fraschetti, S., Gristina, M., Knittweis, L., Martin, C.S. \& Pergent, G. (2015). Seagrass meadows (Posidonia oceanica) distribution and trajectories of change. Scientific Reports 5, 12505.

TeOtia, S. \& Singh, D. (2014). Oxidative stress in plants and its management. In Approaches to Plant Stress and their Management, pp. 227-253. Springer India.

Thomas, R., Unsworth, R.K.F. \& RASHEed, M. (2010). Seagrasses of Port Curtis and Rodds Bay and long term seagrass monitoring, November 2009. Department of Employment, Economic Development and Innovation, Cairns, Australia.

Tol, S.J., JARvis, J.C., York, P.H., GreCH, A., CongdOn, B.C. \& Coles, R.G. (2017). Long distance biotic dispersal of tropical seagrass seeds by marine mega-herbivores. Scientific Reports 7, 4458.

Tomasello, A., Di Maida, G., Calvo, S., Pirrotta, M., Borra, M. \& Procaccini, G. (2009). Seagrass meadows at the extreme of environmental tolerance: the case of Posidonia oceanica in a semi-enclosed coastal lagoon. Marine Ecology 30, 288-300.

TouchetTE, B.W. (2007). Seagrass-salinity interactions: Physiological mechanisms used by submersed marine angiosperms for a life at sea. Journal of Experimental Marine Biology and Ecology 350, 194-215.

Traboni, C., Mammola, S.D., Ruocco, M., Ontoria, Y., Ruiz, J.M., Procaccini, G. \& MARÍN-GUIRAO, L. (2018). Investigating cellular stress response to heat stress in the seagrass Posidonia oceanica in a global change scenario. Marine Environmental Research 141, 12-23. 
Trevathan-Tackett, S.M., Seymour, J.R., Nielsen, D.A., Macreadie, P.I., JefFries, T.C., SAnderman, J., Baldock, J., Howes, J.M., Steven, A.D.L. \& RalPh, P.J. (2017). Sediment anoxia limits microbial-driven seagrass carbon remineralization under warming conditions. FEMS Microbiology Ecology 93, fix033.

Trisos, C.H., Merow, C. \& Pigot, A.L. (2020). The projected timing of abrupt ecological disruption from climate change. Nature 580, 496-501.

Tutar, O., Marín-GuiraO, L., Ruiz, J.M. \& Procaccini, G. (2017). Antioxidant response to heat stress in seagrasses. A gene expression study. Marine Environmental Research 132, 94-102.

TUYA, F., HAROUn, R. \& EsPinO, F. (2014). Economic assessment of ecosystem services: monetary value of seagrass meadows for coastal fisheries. Ocean \& Coastal Management 96, 181-187.

Ugarelli, K., Chakrabarti, S., LaAs, P. \& Stingl, U. (2017). The seagrass holobiont and its microbiome. Microorganisms 5, 81 .

UNSWORTH, R.K.F., NORDLUND, L.M. \& CULLEN-UNSWORTH, L.C. (2019). Seagrass meadows support global fisheries production. Conservation Letters 12, e12566.

VAldeZ, S.R., Zhang, Y.S., VAn der Heide, T., VAnderklift, M.A., TARquinio, F., Orth, R.J. \& Silliman, B.R. (2020). Positive Ecological Interactions and the Success of Seagrass Restoration. Frontiers in Marine Science 7, 91.

Van Wesenbeeck, L., Janssens, L., Meeuws, H., Lagatie, O. \& Stuyver, L. (2018). Droplet digital PCR is an accurate method to assess methylation status on FFPE samples. Epigenetics 13, 207-213.

Vandenkoornhuyse, P., Quaiser, A., Duhamel, M., Le Van, A. \& Dufresne, A. (2015). The importance of the microbiome of the plant holobiont. New Phytologist 206, 11961206. 
VIERLING, E. (1991). The roles of heat shock proteins in plants. Annual Review of Plant Biology 42, 579-620.

WALKER, D.I. \& CAMBRIDGE, M.L. (1995). An experimental assessment of the temperature responses of two sympatric seagrasses, Amphibolis antarctica and Amphibolis griffithii, in relation to their biogeography. Hydrobiologia 302, 63-70.

WALKER, D.I. \& MCCOMB, A.J. (1992). Seagrass degradation in Australian coastal waters. Marine Pollution Bulletin 25, 191-195.

Wang, X., XIN, C., CaI, J., Zhou, Q., DaI, T., CaO, W. \& JiAng, D. (2016). Heat priming induces trans-generational tolerance to high temperature stress in wheat. Frontiers in Plant Science 7, 501.

Waycott, M., Duarte, C.M., Carruthers, T.J.B., Orth, R.J., Dennison, W.C., Olyarnik, S., Calladine, A., Fourqurean, J.W., Heck, K.L. \& HugheS, A.R. (2009). Accelerating loss of seagrasses across the globe threatens coastal ecosystems. Proceedings of the National Academy of Sciences 106, 12377-12381.

Wernberg, T., Bennett, S., BABcock, R.C., De Bettignies, T., Cure, K., DePcZynski, M., Dufois, F., Fromont, J., Fulton, C.J., Hovey, R.K., Harvey, E.S., Holmes, T.H., KENDRICK, G.A., RADFORD, B., SANTANA-GARCON, J., ET AL. (2016). Climate-driven regime shift of a temperate marine ecosystem. Science 353, 169-172.

Wilkinson, A.D., Collier, C.J., Flores, F., LANGlois, L., RAlPh, P.J. \& NeGRi, A.P. (2017). Combined effects of temperature and the herbicide diuron on Photosystem II activity of the tropical seagrass Halophila ovalis. Scientific Reports 7, 45404.

Wilkinson, A.D., Collier, C.J., Flores, F. \& Negri, A.P. (2015). Acute and additive toxicity of ten photosystem-II herbicides to seagrass. Scientific Reports 5, 17443.

Willette, D.A. \& Ambrose, R.F. (2012). Effects of the invasive seagrass Halophila stipulacea on the native seagrass, Syringodium filiforme, and associated fish and 
epibiota communities in the Eastern Caribbean. Aquatic Botany 103, 74-82.

1672

1673

1674

1675

1676

1677

1678

1679

1680

1681

1682

1683

1684

1685

1686

1687

1688

1689

1690

1691

1692

1693

1694

1695

WILLIAMS, S.L. (2001). Reduced genetic diversity in eelgrass transplantations affects both population growth and individual fitness. Ecological Applications 11, 1472-1488.

Winters, G., Beer, S., Willette, D.A., Viana, I., Chiquillo, K.L., BecA-Carretero, P., Betty Villamayor, B., Azcárate-García, T., Shem-Tov, R. \& Mwabvu, B. (2020). The tropical seagrass Halophila stipulacea: reviewing what we know from its native and invasive habitats, alongside identifying knowledge gaps. Frontiers in Marine Science 7, 300.

Winters, G., EdElist, D., ShEM-Tov, R., BeER, S. \& Rilov, G. (2017). A low cost fieldsurvey method for mapping seagrasses and their potential threats: an example from the northern Gulf of Aqaba, Red Sea. Aquatic Conservation: Marine and Freshwater Ecosystems 27, 324-339.

Winters, G., Nelle, P., Fricke, B., RAuch, G. \& Reusch, T.B.H. (2011). Effects of a simulated heat wave on photophysiology and gene expression of high-and low-latitude populations of Zostera marina. Marine Ecology Progress Series 435, 83-95.

Wissler, L., Codõer, F.M., Gu, J., Reusch, T.B., Olsen, J.L., Procaccini, G. \& BORNBERG-BAUER, E. (2011). Back to the sea twice: Identifying candidate plant genes for molecular evolution to marine life. BMC Evolutionary Biology 11, 8.

Yaping, G., Zenguie, J., Meirong, D., Jinghui, F., Weiwei, J. \& Jianguang, F. (2019). Photosynthetic and metabolic responses of eelgrass Zostera marina L. to short-term high-temperature exposure. Journal of Oceanology and Limnology 37, 199-209.

York, P.H., GRUBER, R.K., Hill, R., RAlPh, P.J., BoOTh, D.J. \& MACREADIE, P.I. (2013). Physiological and morphological responses of the temperate seagrass Zostera muelleri to multiple stressors: investigating the interactive effects of light and temperature. PloS One 8, e76377. 
ZHANG, D., ZHANG, Q.S. \& YANG, X.Q. (2017). Adaptive strategies of Zostera japonica photosynthetic electron transport in response to thermal stress. Marine Biology 164, 35.

Zimmerman, R.C., HiLl, V.J. \& Gallegos, C.L. (2015). Predicting effects of ocean warming, acidification, and water quality on Chesapeake region eelgrass. Limnology and Oceanography 60, 1781-1804.

ZimMERMAN, R.C., SMITH, R.D. \& ALBERTE, R.S. (1989). Thermal acclimation and wholeplant carbon balance in Zostera marina L.(eelgrass). Journal of Experimental Marine Biology and Ecology 130, 93-109.

\section{SUPPORTING INFORMATION}

Additional supporting information may be found online in the Supporting Information section at the end of the article.

Table S1. List of thermal-related studies on seagrasses from 1985 to 2020. Data were collected from Google Scholar as indicated in the legend to Fig.1.

Table S2. Number of studied populations from each seagrass species used for thermal-related studies from 1985 to 2020. Data were collected from Google Scholar as indicated in the legend to Fig.1.

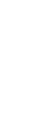

(1)

6

17




\section{Figure legends}

1722 Fig. 1. Ocean warming and thermal-related studies in seagrasses. (A) Increase in sea surface

1723 temperature (SST $\max$ ) over this century adapted from Jordà et al. (2012). Grey lines: the

1724 outputs of single general (atmospheric-ocean general circulation models) models; purple and

1725 blue lines, respectively: the outputs of PROTHEUS and VANIMEDAT2 (regional) models;

1726 red line: the ensemble average (Jordà et al., 2012). (B) Increase in the number of annual

1727 marine heatwave (MHW) days from 1950 to present, and predicted values to 2100, adapted

1728 from Oliver et al. (2019). Annual time series for historical (black), RCP4.5 (brown; which

1729 assumes anthropogenic greenhouse gas emissions peak in the year 2040 and then stabilize at

1730 a radiative forcing of $4.5 \mathrm{~W} \mathrm{~m}^{-2}$ ), and $\mathrm{RCP} 8.5$ (red; which assumes these emissions continue

1731 to rise throughout the 21 st century with radiative forcing reaching $8.5 \mathrm{~W} \mathrm{~m}^{-2}$ by the end of

1732 the century) runs. The gray, red, and brown shaded regions indicate the maximum range

1733 between individual model runs. The blue shaded areas present the expected range of natural

1734 variability based on a 66\% confidence interval (darkest blue), 95\% confidence interval

1735 (medium blue), and full min-to-max range (lightest blue) of the historicalNat (which

1736

represents historical conditions without anthropogenic influence where models are forced by

1737

natural volcanic and solar forcing only, with greenhouse gases and aerosols held at pre-

1738

industrial levels, spanning 1850-2005) runs (Oliver et al., 2019). (C) Number of publications

1739 related to thermal stress studies in seagrasses from 1985 to 2020 across four different levels:

1740 molecular (blue), biochemical/physiological (red), morphological/population (green), and ecosystem/planetary (purple). Data were collected from Google Scholar using the key words

1742 "seagrass thermal stress", "seagrass heat stress", "seagrass temperature" and "seagrass warming" together with personal knowledge from the authors. 
Fig. 2. Common effects and responses of thermal stress on seagrasses at the molecular, biochemical/physiological and morphological level. HSP, heat shock protein; ROS, reactive oxygen species.

Fig. 3. Conceptual diagram summarizing the fate of seagrass populations under conditions of ocean warming as illustrated by Posidonia oceanica in the Mediterranean Sea. Blue carbon is the carbon stored in coastal and marine ecosystems.

1752

Fig. 4. World map of seagrass populations used for thermal-related studies from 1985 to 2020. Coloured symbols indicate study populations, with symbols sizes scaled according to the key on the left. World distributions of species are shown by background green shading, with species numbers indicated according to the key on the right. Data were collected from Google Scholar as indicated in the legend to Fig.1. Figure created by adapting Fig. 3 in Short et al. (2007). Details of locations and related publications are provided in Table S1. 

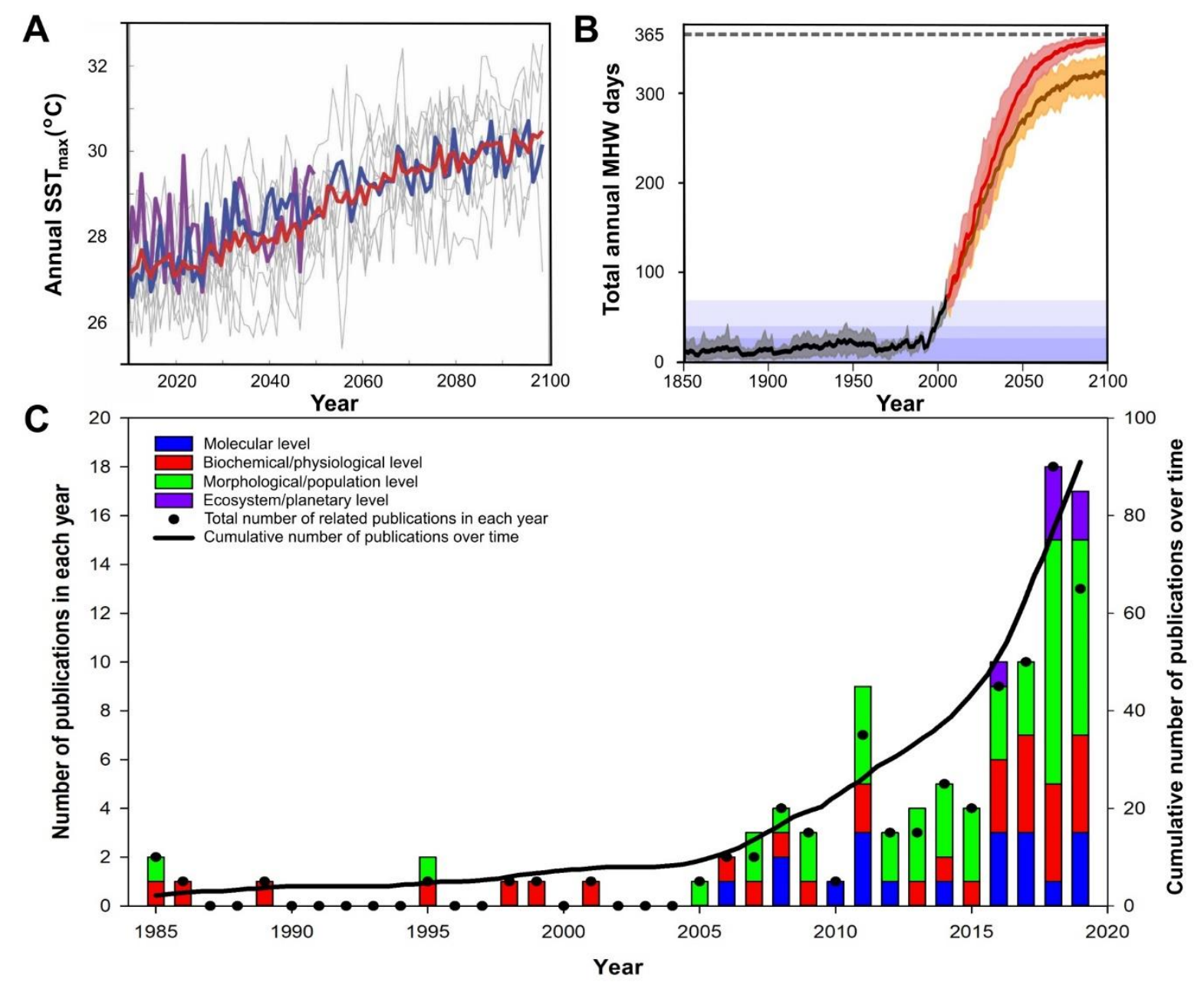

1770

1771 Figure 1

1772

1773

1774

1775

1776

1777

1778

1779

1780

1781

1782

1783

1784 


\begin{tabular}{|c|c|c|}
\hline & Negative effects of thermal stress on seagrasses & Responses of seagrasses \\
\hline 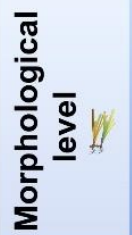 & $\begin{array}{l}\text { Decrease in growth rate } \\
\text { Decrease in number of leaves/shoots } \\
\text { - Decrease in leaf size } \\
\text { * Increase in mortality }\end{array}$ & $\begin{array}{l}\text { Decrease in growth rate } \\
\text { ABt Decrease in above/below-ground biomass ratio } \\
\text { DD Heat stress-induced flowering } \\
\text { (4V) Anticipation of flowering time }\end{array}$ \\
\hline 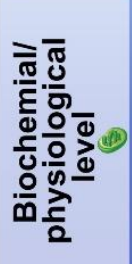 & $\begin{array}{l}\text { (Nifm Decrease in photosynthetic capacity } \\
\text { Increase in respiration } \\
\mathbf{S}^{2} \mathbf{t} \text { Increase in sulfide stress } \\
\text { Damage of cellular membrane fluidity }\end{array}$ & $\begin{array}{l}\text { Neat Activation of photoprotective mechanism } \\
\text { (4) Increase in photoprotective pigments } \\
\text { (18) Changes ification of fatty acid content } \\
\text { Modification of ultirastructure and microtubules }\end{array}$ \\
\hline 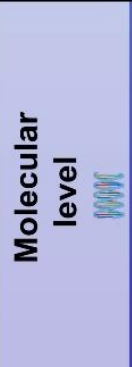 & $\begin{array}{l}\text { ROSI) ROS production } \\
\text { Protein unfolding and degradation } \\
\text { Enhancement of disease impacts } \\
\text { Disruption of translational machinery } \\
\text { Cytoskeleton organization damage } \\
\text { Abnormal cell divisions } \\
\text { DNA damage }\end{array}$ & $\begin{array}{l}\text { HSPI Production of HSP and chaperones } \\
\text { S001 Increase in antioxidant defences } \\
\text { Proteolysis and ubiquitination } \\
\text { EPI Epigenetic modification } \\
\text { (8) Cell wall fortification } \\
\text { DNA repair } \\
\text { Apoptosis }\end{array}$ \\
\hline
\end{tabular}

1786 Figure 2

1787

1788

1789

1790

1791

1792

1793

1794

1795

1796

1797

1798

1799

1800

1801 


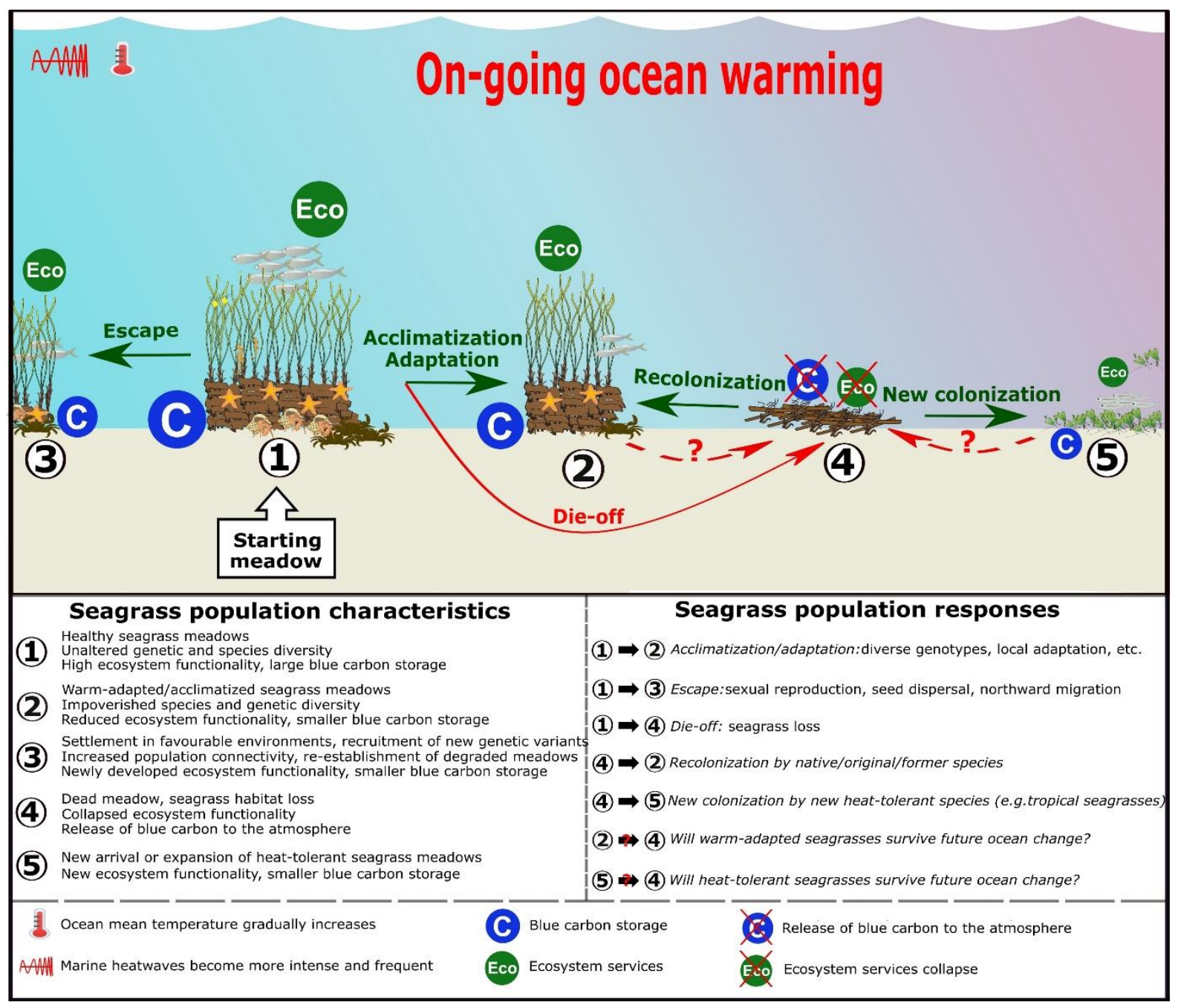

Figure 3 


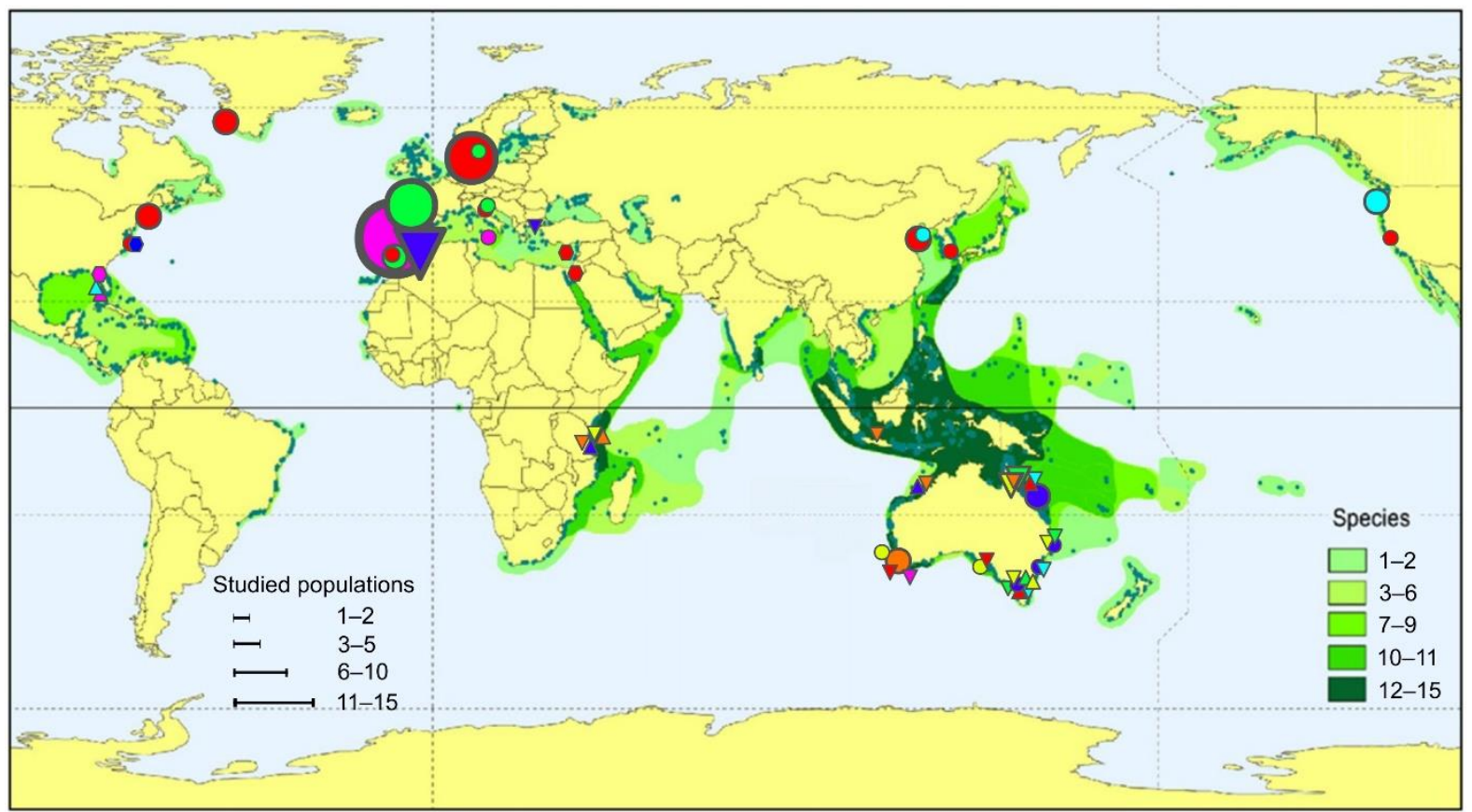

Seagrass species from thermal-related studies

- Zostera marina O Zostera noltii

$\nabla$ Posidonia sinuosa

Posidonia oceanica

- Zostera muelleri

Amphibolis antarctica

$\nabla$ Cymodocea nodosa
$\nabla$ Halophila ovalis

$\nabla$ Cymodocea serrulata $\boldsymbol{\Delta}$ Enhalus acoroides

Zostera japonica

$\checkmark$ Posidonia australis

$\nabla$ Halodule uninervis

$\nabla$ Thalassia hemprichii $\triangle$ Halodule wrightii

$\triangle$ Thalassodendron ciliatum

Figure 4

1817 